\title{
Muscle Fibers Secrete FGFBP1 to Slow Degeneration of Neuromuscular Synapses during Aging and Progression of ALS
}

\author{
Thomas Taetzsch, ${ }^{1 \star}$ Milagros J. Tenga, ${ }^{1 *}$ and Gregorio Valdez ${ }^{1,2}$ \\ ${ }^{1}$ Virginia Tech Carilion Research Institute, Virginia Tech, Roanoke, Virginia 24016, and ${ }^{2}$ Department of Biological Sciences, Virginia Tech, Blacksburg, \\ Virginia 24061
}

\begin{abstract}
The identity of muscle secreted factors critical for the development and maintenance of neuromuscular junctions (NMJs) remains largely unknown. Here, we show that muscle fibers secrete and concentrate the fibroblast growth factor binding protein 1 (FGFBP1) at NMJs. Although FGFBP1 expression increases during development, its expression decreases before NMJ degeneration during aging and in SOD1 ${ }^{\mathrm{G} 93 \mathrm{~A}}$ mice, a mouse model for amyotrophic lateral sclerosis (ALS). Based on these findings, we examined the impact of deleting FGFBP1 on NMJs. In the absence of FGFBP1, NMJs exhibit structural abnormalities in developing and middle age mice. Deletion of FGFBP1 from SOD $1{ }^{\mathrm{G} 93 \mathrm{~A}}$ mice also accelerates NMJ degeneration and death. Based on these findings, we sought to identify the mechanism responsible for decreased FGFBP1 in stressed skeletal muscles. We show that FGFBP1 expression is inhibited by increased accumulation of the transforming growth factor- $\beta 1$ (TGF- $\beta 1$ ) in skeletal muscles and at their NMJs. These findings suggest that targeting the FGFBP1 and TGF- $\beta 1$ signaling axis holds promise for slowing age- and disease-related degeneration of NMJs.
\end{abstract}

Key words: axonal regeneration; cytokine; geriatric; Lou Gehrig's disease; synaptic elimination; target-derived

\section{Significance Statement}

The neuromuscular junction (NMJ) is critical for all voluntary movement. Its malformation during development and degeneration in adulthood impairs motor function. Therefore, it is important to identify factors that function to maintain the structural integrity of NMJs. We show that muscle fibers secrete and concentrate the fibroblast growth factor binding protein 1 (FGFBP1) at NMJs. However, FGFBP1 expression decreases in skeletal muscles during aging and before NMJ degeneration in SOD $1{ }^{\mathrm{G} 93 \mathrm{~A}}$ mice, a mouse model for amyotrophic lateral sclerosis. We show that transforming growth factor- $\beta 1$ is responsible for the decreased levels of FGFBP1. Importantly, we demonstrate critical roles for FGFBP1 at NMJs in developing, aging and SOD1 ${ }^{\mathrm{G} 93 \mathrm{~A}}$ mice.

\section{Introduction}

The neuromuscular junction (NMJ) is critical for the function and survival of $\alpha$-motor neurons and skeletal muscles. Although this synapse remains largely intact during the juvenile phase and most of adulthood, it undergoes deleterious functional and struc-

\footnotetext{
Received Sept. 23, 2016; revised Nov. 2, 2016; accepted Nov. 7, 2016.

Author contributions: T.T., M.J.T., and G.V. designed research; T.T., M.J.T., and G.V. performed research; G.V. contributed unpublished reagents/analytic tools; T.T., M.J.T., and G.V. analyzed data; T.T., M.J.T., and G.V. wrote the paper.

This work supported by the National Institutes of Health (National Institute of Neurological Disorders and Stroke Grant K01NS085071 and National Institute on Aging Grant R56AG051501 to G.V.). We thank present and past members of the Valdez laboratory, in particular Sihui Zhang, Nicholas Maxwell, Sydney Vaughan, Vanessa Brayman, and Satoshi Sugita, for their support with mouse husbandry, gene expression analysis, and intellectual input.

The authors declare no competing financial interests.

*T.T. and M.J.T. contributed equally to this work.

Correspondence should be addressed to Gregorio Valdez, Virginia Tech Carilion Research Institute, Virginia Tech,

2 Riverside Circle, Roanoke, VA 24016. E-mail: gvaldez1@vtc.vt.edu.

DOI:10.1523/JNEUROSCI.2992-16.2016

Copyright $\odot 2017$ the authors $\quad 0270-6474 / 17 / 370070-13 \$ 15.00 / 0$
}

tural changes during normal aging and progression of a variety of diseases, including amyotrophic lateral sclerosis (ALS) (Valdez et al., 2010; Bayat et al., 2011; Moloney et al., 2014; Filézac de L'Etang et al., 2015; Valsecchi et al., 2015). In fact, it has been proposed recently that deleterious changes at the NMJ may precede and contribute to degeneration of motor neurons and atrophy of muscle fibers (Fahim and Robbins, 1982; Fahim et al., 1983; Cardasis and LaFontaine, 1987.; Kennel et al., 1996; Li et al., 2011; Rocha et al., 2013). Therefore, it is plausible that molecules that function to maintain adult NMJs could have therapeutic benefits for slowing degeneration of the motor system. The fibroblast growth factor binding protein 1 (FGFBP1) was identified recently as a candidate molecule for promoting repair of NMJs (Williams et al., 2009).

FGFBP1 is a secreted molecule that functions to chaperone fibroblast growth factor (FGF) ligands from the extracellular matrix to cognate receptors (Wu et al., 1991; Tassi et al., 2001; Abuharbeid et al., 2006) and thus enhances the biological activity of 
FGF ligands. FGFBP1 has been shown to accelerate the repair of skin and kidney tissues after injury through its interaction with select FGF ligands, including those involved in synapse formation (e.g., FGF-7/10/22) (Beer et al., 2005; Tassi et al., 2007, 2011). In skeletal muscles, FGFBP1 was identified as a candidate molecule used by the muscle and synaptic-enriched microRNA miR-206 to promote regeneration of NMJs in mice (Williams et al., 2009). Most recently, miR-206 was shown to modulate levels of FGFBP1 in the myogenic cell line C2C12 (Valsecchi et al., 2015). In addition, FGFBP1 was found upregulated in quadriceps muscles in a mouse model for spinal muscular atrophy (Valsecchi et al., 2015). Despite these findings, little is known regarding the function of FGFBP1 in skeletal muscles and NMJs (Williams et al., 2009). In addition, the signaling events and downstream effectors that affect FGFBP1 expression in concert or in parallel with miR-206 remain unknown.

Here, we performed a detailed analysis of FGFBP1 expression and function in skeletal muscles from developing, adult, aging, and disease-afflicted mice. We show that FGFBP1 concentrates at NMJs and its expression is reduced in ALS-affected and aged muscles. Using knock-out mice, we found that FGFBP1 plays critical functions at NMJs during development and aging and in mice harboring the ALS-causing mutant gene SOD1 ${ }^{\mathrm{G} 93 \mathrm{~A}}$ (Gurney et al., 1994). Based on these findings, we sought to uncover the mechanism that suppresses FGFBP1 expression in stressed muscles. Data obtained from in vitro and in vivo experiments strongly suggest that the transforming growth factor- $\beta 1$ (TGF$\beta 1$ ) suppresses FGFBP1. In addition, we found TGF- $\beta 1$ highly concentrated at NMJs of presymptomatic SOD $1^{\mathrm{G} 93 \mathrm{~A}}$ mice, suggesting that it may affect FGFBP1 levels directly at the NMJ. Our data have identified a muscle-derived secreted factor that contributes to the maintenance of NMJs and revealed the TGF- $\beta 1$ pathway as a potential target for preventing loss of endogenous FGFBP1 and preserving the structural integrity of NMJs in aged and disease-afflicted animals.

\section{Materials and Methods}

\section{Animals}

FGFBP1 knock-out $\left(\mathrm{FGFBP}^{-/-}\right.$) mice were generated by standard homologous recombination procedures in embryonic stem (ES) cells. The FGFBP1-targeting vector was generated by PCR in which the $5^{\prime}$ and $3^{\prime}$ arms were ligated to a selection cassette containing an IRES- $\beta$-galactosidase/Neomycin fusion (BetaGeo), along with a puromycin resistance marker. Upon electroporation into 129S5 (Lex2) ES cells (RRID: CVCL_0J18), homologous recombination resulted in the deletion of the entire coding region of the FGFBP1 gene and replacement with the selectable marker. Correctly targeted ES cells were confirmed by Southern blot analysis and injected into C57BL/6J (albino) blastocysts. The resulting heterozygous animals were identified by PCR. Heterozygous animals were intercrossed to produce the homozygous mutant FGFBP1 $1^{-1-}$ animals. The following mice were obtained from The Jackson Laboratory: SOD1 ${ }^{\mathrm{G} 93 \mathrm{~A}}$ (RRID:IMSR_JAX:004435; Gurney et al., 1994), Parvalbumin-Cre (RRID:IMSR_JAX:017320; Hippenmeyer et al., 2005; referred to herein as PVCre), Thy1-YFP16 (RRID:IMSR_JAX:003709; Feng et al., 2000; referred to herein as THYFP16), and RiboTag (RRID: IMSR_JAX:011029; Sanz et al., 2009) mice. To visualize motor axons, THYFP16 mice were crossed with $\mathrm{SOD} 1^{\mathrm{G} 93 \mathrm{~A}}, \mathrm{FGFBP} 1^{-1-}$, and SOD $1^{\mathrm{G}^{2} 3 \mathrm{~A}}$;FGFBP1 ${ }^{-1-}$ mice. To immunoprecipitate ribosomes from muscle fibers, mice expressing hemagglutinin (HA)-tagged ribosomal protein L22 (referred to herein as Ribotag mice) were mated with PVCre mice (referred to herein as PVCre;Ribotag mice). All experiments were performed under National Institutes of Health guidelines and animal protocols approved by the Virginia Tech Institutional Animal Care and Use Committee.
Table 1. Sequences of primers used for $\mathrm{qPCR}$

\begin{tabular}{|c|c|c|}
\hline Gene & Forward primer & Reverse primer \\
\hline $\mathrm{AChR} \gamma$ & 5'-GCTCAGCTGCAAGTTGATCTC-3' & 5'-CCTCCTGCTCCATCTCTGTC-3' \\
\hline $\mathrm{AChR} \epsilon$ & 5'-GCTGTGTGGATGCTGTGAAC-3' & 5'-GCTGCCCAAAAACAGACATT-3' \\
\hline FGFBP1 & $5^{\prime}$-ACACTCACAGAAAGGTGTCCA-3' & $5^{\prime}-$ CTGAGAACGCCTGAGTAGCC-3' \\
\hline Fox01 & 5'-GAGTTAGTGAGCAGGCTACATTT-3' & 5'-TTGGACTGCTCCTCAGTTCC-3' \\
\hline Fox03 & $5^{\prime}$-CAAAGCAGACCCTCAAACTGACG-3' & 5'-AGGTGTCAAGCTGTAAACGGA-3 \\
\hline GAPDH & 5'-СССАСТCTTCCACCTTCGATG-3' & 5'-GTCCACCACCCTGTTGCTGTAG-3 \\
\hline Musk & $5^{\prime}$-CCACACTGCGTGGAATGAGC-3' & 5'-CTCTGCAAATGGGCATGGG-3' \\
\hline Pax7 & $5^{\prime}$-GCGAGAAGAAAGCCAAACAC-3' & 5'-GTCGGGTTCTGATTCCACAT-3' \\
\hline TGF- $\beta 1$ & 5'-GTCACTGGAGTTGTACGGCA-3' & 5'-AGCCCTGTATTCCGTCTCCT-3' \\
\hline TGF- $\beta 2$ & 5'-ACTGCTTTAGAAATGTGCAGGAT-3' & 5'-AGATCCTGGGACACACAGCA-3' \\
\hline TGF- $\beta 3$ & 5'-GCACTTTACAACAGCACCCG-3' & 5'-AGTTCATTGTGCTCCGCCAG-3' \\
\hline
\end{tabular}

\section{Synaptic diaphragm dissection}

To analyze synaptic mRNA expression, female THYFP16 mice aged 3-5 months with selective yellow fluorescence protein (YFP) expression in motor neurons were killed with isoflurane and the synaptic regions of the left and right diaphragm from each mouse were dissected by visualizing $\mathrm{YFP}+$ motor neurons using a Zeiss Discovery Z20 fluorescence dissecting microscope (Valdez et al., 2014).

\section{C2C12 cell culture}

Unfused C2C12 myoblasts (RRID:CVCL_0188) were maintained in DMEM containing $20 \%$ fetal bovine serum (FBS), $0.1 \%$ penicillin/streptomycin (Pen/Strep), $2 \mathrm{~mm}$ glutamine, and $0.1 \%$ Fungizone at $37^{\circ} \mathrm{C}$ and $5 \% \mathrm{CO}_{2}$. To induce $\mathrm{C} 2 \mathrm{C} 12$ cell fusion, cells were seeded to polyornithine $(3 \mu \mathrm{g} / \mathrm{ml}) / \mathrm{laminin}(10 \mu \mathrm{g} / \mathrm{ml})$-coated 8 -well chamber slides at a concentration of $5 \times 10^{4}$ cells per well in $20 \%$ FBS DMEM. At $24 \mathrm{~h}$ after seeding, cell culture medium was replaced with cell fusion medium consisting of DMEM containing 2\% horse serum, 0.1\% Pen/Strep, $2 \mathrm{~mm}$ glutamine, and $0.1 \%$ Fungizone. Treatments of fused $\mathrm{C} 2 \mathrm{C} 12$ cells were performed $72 \mathrm{~h}$ after the addition of fusion medium. Reagents used for treatment include recombinant neural-agrin (z-agrin) $10 \mathrm{ng} / \mathrm{ml}(\mathrm{R} \& \mathrm{D}$ Systems), carbachol $10 \mu \mathrm{M}$ (Sigma-Aldrich), recombinant TGF- $\beta 15$ $\mathrm{ng} / \mathrm{ml}$ (Humanzyme), and SB431542 $5 \mu \mathrm{M}$ (Cayman Chemical).

$m R N A$ analysis

Total RNA was extracted from skeletal muscle and cell cultures using TRIzol reagent (Life Technologies) and the Aurum Total RNA Mini Kit (Bio-Rad). RNA was reverse transcribed using iScript Reverse Transcription Supermix (Bio-Rad). Quantitative PCR (qPCR) was performed with iTAQ SYBR Green Supermix (Bio-Rad) containing $300 \mathrm{~nm}$ forward and reverse primers using the CFX Connect Real Time PCR System (Bio-Rad). Cycling parameters were $95^{\circ} \mathrm{C}$ for $30 \mathrm{~s}, 40$ cycles of $95^{\circ} \mathrm{C}(5 \mathrm{~s})$, and $58^{\circ} \mathrm{C}(30 \mathrm{~s})$, followed by a melting curve consisting of $5 \mathrm{~s} 0.5^{\circ} \mathrm{C}$ incremental increases ranging from $65^{\circ} \mathrm{C}$ to $95^{\circ} \mathrm{C}$. Primer sequences used in this study are listed in Table 1.

\section{Ribosomal immunoprecipitation}

PVCRE;Ribotag mice expressing HA-tagged ribosomal protein L22 (Rpl22) were used to isolate ribosome-mRNA complexes specifically from mature fast-type skeletal muscle fibers within muscle tissue. The parvalbumin promoter is selectively active in fast-type muscle fibers within skeletal muscle fibers (Celio and Heizmann, 1982). This allows for Cre and HA-Rpl22 expression in fast-type muscle fibers in PVCRE;Ribotag mice. Tibialis anterior (TA) muscles from PVCRE;Ribotag mice were flash frozen and ground into a fine powder over liquid nitrogen before homogenization with NP40 lysis buffer containing cycloheximide, as well as protease, phosphatase, and RNase inhibitors. Ribosome-mRNA complexes were immunoprecipitated with a mouse monoclonal HA antibody (Covance Research Products catalog \#MMS-101R-500 RRID: AB_10063630) or an antibody against argonaute 2 to serve as a control (Cell Signaling Technology catalog \#2897S RRID:AB_2096291) using protein G-conjugated magnetic beads (Dynabeads Protein G; Life Technologies). 


\section{Western blot}

Immunoprecipitates and whole-cell lysates were diluted in Laemmli buffer and denatured at $95^{\circ} \mathrm{C}$ for $10 \mathrm{~min}$ before electrophoresis on a $12 \%$ SDS-PAGE gel. Samples were transferred to nitrocellulose membrane using wet transfer, blocked for $1 \mathrm{~h}$ at room temperature in blocking solution (5\% nonfat milk diluted in $0.1 \%$ Tween Tris buffer solution), incubated $1 \mathrm{~h}$ at room temperature in anti-HA antibody (Covance Research Products catalog \#MMS-101R-500 RRID:AB_10063630), diluted in blocking solution, washed 3 times with $0.1 \%$ Tween Tris buffer solution, incubated $1 \mathrm{~h}$ at room temperature in 1:10,000 peroxidase labeled secondary antibody (Jackson ImmunoResearch Labs catalog \#715-035151 RRID:AB_2340771), and washed 3 times with $0.1 \%$ Tween Tris buffer solution. Blots were visualized with ECL reagent (GE Healthcare) and ChemiDoc Imager (Bio-Rad).

\section{Ribosomal mRNA isolation}

Skeletal-muscle-specific ribosomal mRNA was evaluated in PVCRE;Ribotag TA and extensor digitorum longus (EDL) muscle fibers after ribosomal immunoprecipitation of ribosome-mRNA complexes with a mouse monoclonal HA antibody (Covance Research Products catalog \#MMS-101R-500 RRID:AB_10063630) as described above. Ten percent of cell lysate was collected before ribosomal immunoprecipitation for total RNA analysis. RNA was isolated from the HA-immunoprecipitated ribosome-mRNA complexes and total cell lysate using the Qiagen RNeasy Plus Micro Kit.

\section{Immunohistochemistry}

Whole mounted muscle. Mice were deeply anesthetized using vaporized isoflurane and fixed by perfusion with $4 \%$ paraformaldehyde in PBS. Muscles were dissected, blocked for $2 \mathrm{~h}$ at room temperature (5\% lamb serum, $3 \% \mathrm{BSA}, 0.5 \%$ Triton $\mathrm{X}-100$ in PBS), incubated with primary antibodies at $4^{\circ} \mathrm{C}$ overnight, washed with PBS 3 times for $5 \mathrm{~min}$, incubated with secondary antibodies and/or fluorescently tagged $\alpha$-bungarotoxin (fBTX) for $2 \mathrm{~h}$ at room temperature, washed with PBS 3 times for $15 \mathrm{~min}$, and whole mounted in Vectashield mounting medium (Vector Laboratories) on slides. Axons were labeled with 1:1000 neurofilament (Covance Research Products catalog \#SMI-312R RRID:AB_2314906) and axon terminals were labeled with 1:250 synaptotagmin-2 (Developmental Studies Hybridoma Bank catalog \#znp-1 RRID:AB_531910). Postsynaptic nicotinic acetylcholine receptor clusters on myotubes were labeled with 1:1000 fBTX (Thermo Fisher Scientific catalog \#B35451 RRID:AB_2617152).

Muscle cross-sections. Fresh TA muscle was dissected and embedded in tissue-freezing medium (General Data Healthcare) at $-80^{\circ} \mathrm{C}$. The embedded TA was sectioned at $16 \mu \mathrm{m}$ using a cryostat and collected on gelatin-coated slides. Sections were blocked for $1 \mathrm{~h}$ at room temperature (5\% lamb serum, 3\% BSA, 0.1\% Triton X-100 in PBS), incubated with primary antibodies overnight at $4^{\circ} \mathrm{C}$, washed with PBS 3 times for $5 \mathrm{~min}$, incubated with secondary antibodies for $1 \mathrm{~h}$ at room temperature, washed with PBS 3 times for $5 \mathrm{~min}$, and mounted in Vectashield. Primary antibodies used for muscle cross-sections include 1:100 FGFBP1 (Bioss catalog \#bs-1768R RRID:AB_10857222) and 1:50 TGF- $\beta 1$ (Santa Cruz Biotechnology catalog \#sc-146 RRID:AB_632486). Postsynaptic nicotinic acetylcholine receptor clusters on myotubes were labeled with 1:1000 fBTX (Thermo Fisher Scientific catalog \#B35451 RRID: AB_2617152).

C2C12 cultures. C2C12 myotubes were fixed in cell culture medium containing $4 \%$ PFA and $4 \%$ sucrose at room temperature for $30 \mathrm{~min}$. The cells were washed with PBS 3 times, incubated in blocking buffer (5\% lamb serum, $3 \%$ BSA, $0.1 \%$ Triton X-100 in PBS) for $30 \mathrm{~min}$, incubated with primary antibody overnight at $4^{\circ} \mathrm{C}$, washed with PBS 3 times for 5 $\mathrm{min}$, incubated with secondary antibodies for $1 \mathrm{~h}$ at room temperature, washed with PBS 3 times for $5 \mathrm{~min}$, and mounted in Vectashield. Mature myotubes were labeled with anti-myosin antibody (Developmental Studies Hybridoma Bank catalog \#MF20 RRID:AB_2147781) at a concentration of 1:100.

\section{Imaging}

Imaging was performed with a laser scanning confocal microscope (Zeiss LSM 710) with either a $20 \times(0.8$ numerical aperture, NA) objective or
$40 \times(1.3 \mathrm{NA})$ oil-immersion objective using Zeiss Zen Black software. Maximum intensity projections of optical sections were created with Zeiss Zen software.

\section{NMJ analysis}

Structural changes of the NMJ were scored based on the definitions described previously (Valdez et al., 2010) using maximum-intensity projections of images acquired from whole-mounted muscles. Briefly, NMJs defined as fragmented contained at least five different noncontiguous AChR clusters. Synaptic apposition is defined as the proportion of the $\mathrm{AChR}$ area colocalized by the axon terminal. Multiple innervation is defined as a single NMJ being occupied by two or more axons. NMJ areas were measured using ImageJ. NMJ innervation analysis was performed on blinded images based on a qualitative assessment of the percentage of AChR area occupied by an axon terminal, where full innervation is defined as $>90 \%$ overlap, partial innervation is defined as $10-90 \%$ overlap, and full denervation is defined as $<10 \%$ overlap. An average of $272 \mathrm{NMJs}$ per animal were analyzed. Synaptic TGF- $\beta 1$ pixel intensity analysis was performed with Zeiss Zen Black software on images acquired from muscle cross sections. Synaptic regions of a muscle section were identified by the presence of AChR clusters labeled with fBTX. Relative TGF- $\beta 1$ pixel intensity is based on comparisons made between muscle sections from control and SOD $1^{\mathrm{G} 93 \mathrm{~A}}$ mice mounted to the same slide using identical confocal microscope settings. An average of $51 \mathrm{NMJs}$ per animal were analyzed for TGF- $\beta 1$ pixel intensity.

\section{Statistical analysis}

Comparisons between two means were performed with independent Welch's or Student's $t$ test and comparisons between three or more means were performed with one-way ANOVA followed by Bonferroni's post hoc analysis. Data are expressed as mean \pm SEM. To assess differences in mouse survival, a log-rank test was performed. A value of $p<$ 0.05 was considered statistically significant.

\section{Results}

\section{Muscle fibers express and concentrate FGFBP1 at NMJs}

The expression of FGFBP1 in skeletal muscles remains largely unexplored despite its proposed role at NMJs (Williams et al., 2009). To fill this gap in knowledge, we examined FGFBP1 levels in the TA muscle of developing and adult mice using qPCR. In the TA muscle of 2-month-old mice, FGFBP1 is expressed at higher levels compared with 8 -d-old mice (Fig. $1 A$ ). We then sought to determine whether muscle fibers express and secrete FGFBP1. For this, we profiled FGFBP1 transcripts in ribosomal mRNA fractions specifically isolated from fast-type muscle fibers within the TA. We accomplished this by crossing mice expressing the ribosomal protein Rpl22 tagged with HA epitopes (Ribo

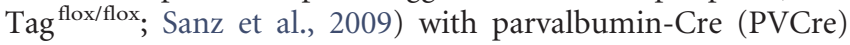
transgenic mice (Hippenmeyer et al., 2005) to generate PVCre; RiboTag ${ }^{\text {flox/flox }}$ offspring. In PVCre; RiboTag ${ }^{\text {flox/flox }}$ mice, HAtagged Rpl22 is expressed in fast-type muscle fibers (Fig. 1B), which constitute the majority of muscle fibers in the TA muscle (Burkholder et al., 1994). We found transcripts for FGFBP1 and the muscle-specific kinase (MuSK; Bowen et al., 1998) enriched in ribosomal mRNA fractions obtained from the TA muscle compared with total muscle mRNA (Fig. 1C). As expected, the satellite cell marker Pax7 (Seale et al., 2001) was nearly absent from the TA muscle ribosomal mRNA fractions compared with total muscle mRNA (Fig. 1C). These findings demonstrate that FGFBP1 is transcribed and likely translated in muscle fibers.

We next investigated whether FGFBP1 concentrates in the muscle synaptic region. First, we compared FGFBP1 transcript levels between microdissected synaptic and nonsynaptic regions of the diaphragm muscle (Valdez et al., 2014). This analysis revealed higher levels of FGFBP1 mRNA in synaptic compared with 
A

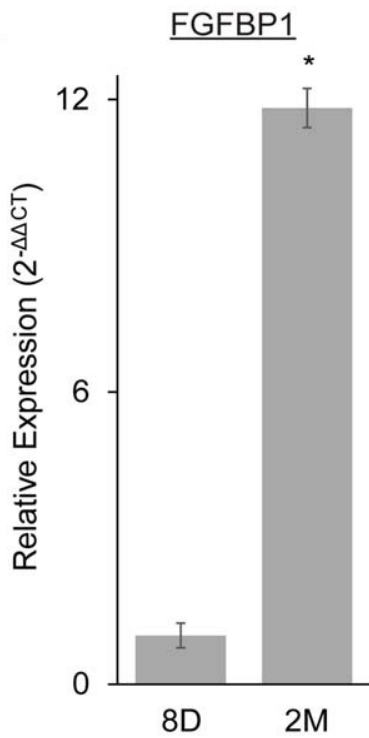

D

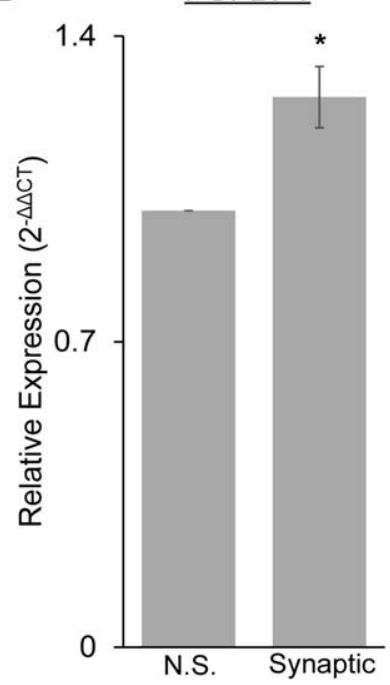

B

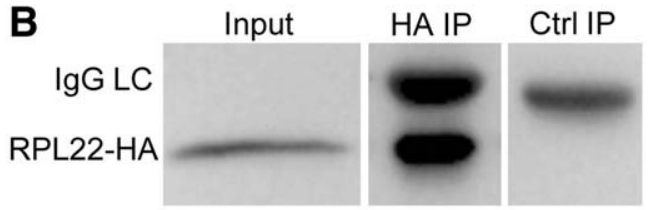

C
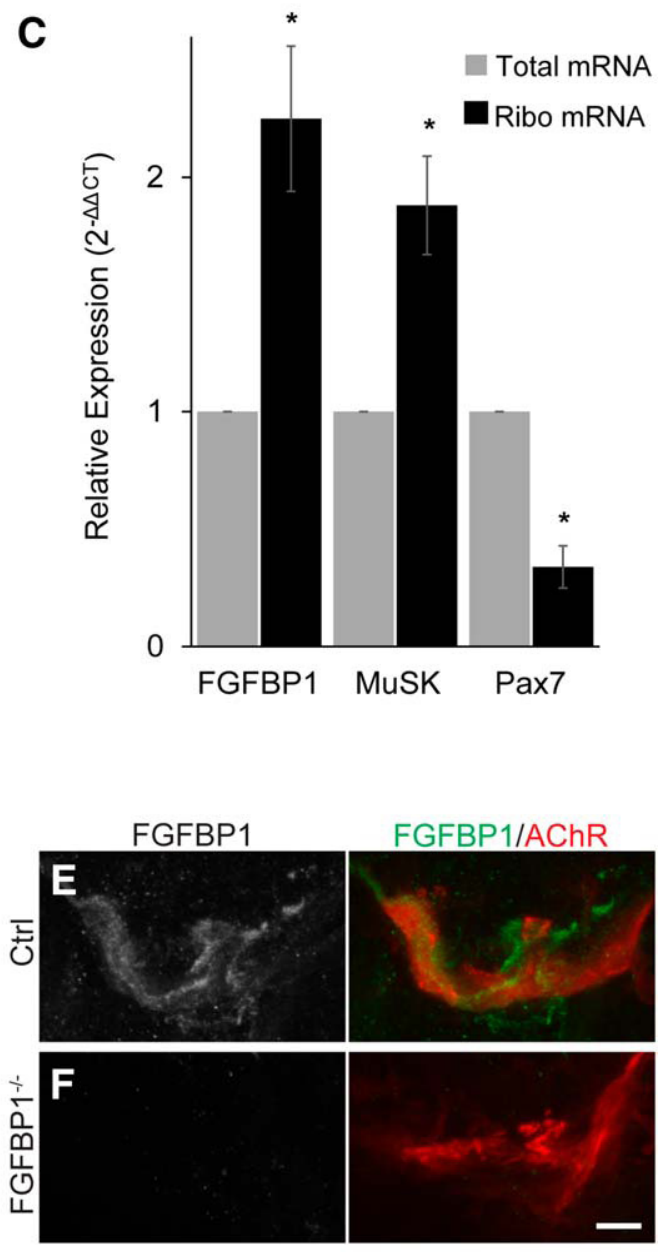

Figure 1. FGFBP1 is generated by skeletal muscle fibers and enriched at NMJs. A, FGFBP1 mRNA is expressed at higher levels in young adult compared with developing muscles $\left(n=3\right.$, unpaired $t$ test: $\left.{ }^{*} p<0.05\right)$. B, HA Western blot of whole-cell lysate (input), immunoprecipitate obtained using an HA antibody (HA IP) or from a nonspecific control antibody (anti-ago2; (trl IP) demonstrates that the HA-tagged RPL22 (Ribotag) protein is expressed in TA muscles from PVCre;Ribotag mice. C, qPCR analysis using mRNA isolated from HA-tagged RPL22-associated ribosomes shows FGFBP1 and the muscle-specific MuSK transcripts enriched in mature skeletal muscle fibers in stark contrast to $\operatorname{Pax} 7\left(n=4\right.$, Welch's $t$ test: $\left.{ }^{*} p<0.05\right)$. D. Transcript analysis also shows FGFBP1 enriched in the synaptic versus nonsynaptic (N.S.) region of diaphragm muscle $\left(n=5\right.$, Welch's $t$ test: $\left.{ }^{*} p<0.05\right) . \boldsymbol{E}, \boldsymbol{F}$, Immunostaining showing FGFBP1 present at NMJs of control mice but completely missing from NMJs of FGFBP1 ${ }^{-1-}$ mice. Scale bar, $5 \mu \mathrm{m}$. Values are reported as mean \pm SEM. mRNA expression was normalized to GAPDH using $2^{-\Delta \Delta C T}$.

nonsynaptic regions of the muscle (Fig. 1D), a relationship found for other molecules with important roles at NMJs including the epsilon subunit of the muscle nicotinic AChR (nAChR) (Kishi et al., 2005). We then used immunostaining to visualize FGFBP1 at the NMJ. To locate NMJs, the EDL muscle was labeled with fBTX, which binds with high affinity to muscle nAChRs concentrated at the postsynaptic region of the NMJ. Although FGFBP1 is present at NMJs of control mice (Fig. $1 E$ ), it is completely missing from FGFBP $^{-/-}$mice (described below; Fig. $1 F$ ).

\section{FGFBP1 deletion delays maturation of NMJs}

To assess the function of FGFBP1 at NMJs, we generated FGFBP $1^{-1-}$ mice. Southern blotting validated deletion of the
FGFBP1 locus (Fig. 2A). As expected, FGFBP1 transcripts were completely absent from the TA muscle of FGFBP1 ${ }^{-1-}$ mice (Fig. 2B). FGFBP1 ${ }^{-1-}$ mice are born at normal Mendelian rates, do not exhibit obvious outward developmental defects, and appear indistinguishable from control mice. We first examined NMJs in the EDL muscle of developing and juvenile FGFBP $1^{-/-}$and control mice using light microscopy. We stained motor axon nerve terminals constituting the presynaptic site with an antibody against synaptotagmin-2. The postsynaptic site was labeled using fBTX. We found that the presynaptic and postsynaptic sites of the NMJ were less apposed at postnatal day 8 (P8) FGFBP $1^{-/-}$mice compared with control mice of the same age (Fig. $2 C, D, G$ ). We also found more multiply innervated NMJs in $\mathrm{P} 8 \mathrm{FGFBP} 1^{-1-}$ mice compared with control mice (Fig. 2E,F,H). However, NMJs lacking FGFBP1 continued to mature and were structurally indistinguishable from those in control mice by P16 (Fig. $3 A-D$ ) and P45 (Fig. 3E-H). These data suggest that FGFBP1 primarily affects the rate of presynaptic maturation. Accordingly, we found no difference in the overall size of the NMJ in P8 (Fig. 2I), P16 (Fig. $3 D$ ), or P45 (Fig. $3 H$ ) muscle. These findings corroborate previous observations showing that reducing FGFBP1 levels using RNA interference slows the development of NMJs (Williams et al., 2009).

Loss of FGFBP1 accelerates ALS-related pathogenesis in SOD1 ${ }^{\mathrm{G} 93 \mathrm{~A}}$ mice

FGFBP1 was initially proposed to slow the progression of ALS-related pathology, starting with preservation of NMJs, in mice expressing SOD ${ }^{\text {G93A }}$. To date, however, there are no data directly implicating FGFBP1 in ALS-related pathogenesis. To fill this gap in knowledge, we assessed FGFBP1 expression in the TA muscle of presymptomatic (70-d-old) and early symptomatic (90-d-old) male SOD $1^{\text {G93A }}$ mice. We found FGFBP1 transcripts significantly reduced in presymptomatic and early symptomatic TA muscles of SOD $1^{\mathrm{G} 93 \mathrm{~A}}$ mice compared with control mice of the same age and sex (Fig. 4A).

To determine the function of FGFBP1 in ALS-related pathology, we generated SOD $1^{\mathrm{G} 93 \mathrm{~A}}$ mice lacking FGFBP1 $\left(\mathrm{SOD} 1^{\mathrm{G} 93 \mathrm{~A}}\right.$;FGFBP $1^{-/-}$). To facilitate analysis of motor axons, SOD1 ${ }^{\mathrm{G} 93 \mathrm{~A}}$ mice with and without FGFBP1 were crossed with Thy1-YFP transgenic mice to label all motor axons. In 90-d-old SOD $1^{\mathrm{G} 93 \mathrm{~A}}$;FGFBP $1^{-/-}$mice, there were fewer fully innervated NMJs in the EDL muscle compared with SOD ${ }^{\text {G93A }}$ mice expressing FGFBP1 (Fig. $4 B-D$ ). Instead, SOD ${ }^{\mathrm{G} 93 \mathrm{~A}}$ mice lacking FGFBP1 contained more partially and completely denervated NMJs in the EDL muscle at $90 \mathrm{~d}$ of age (Fig. $4 B-E$ ). Not surpris- 
A

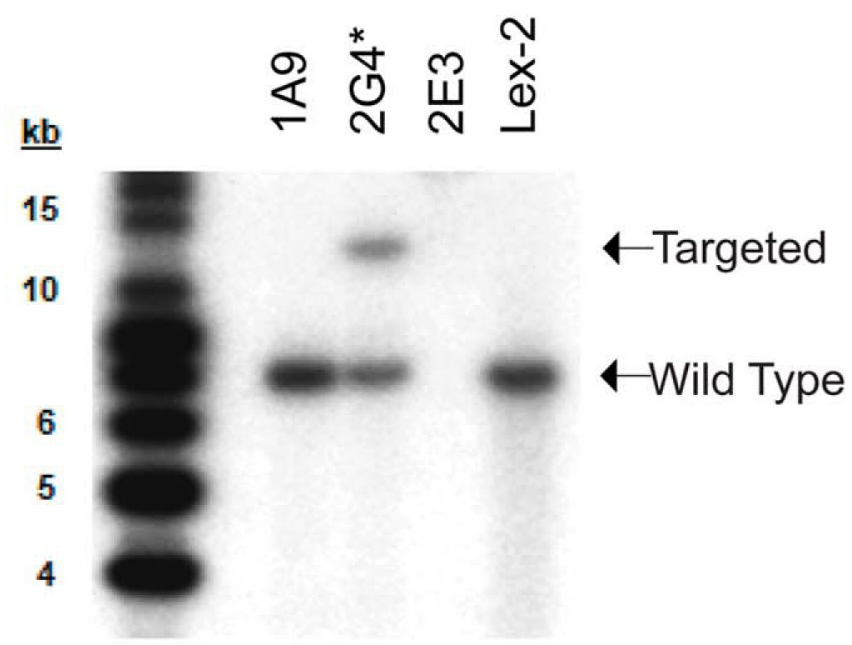

B

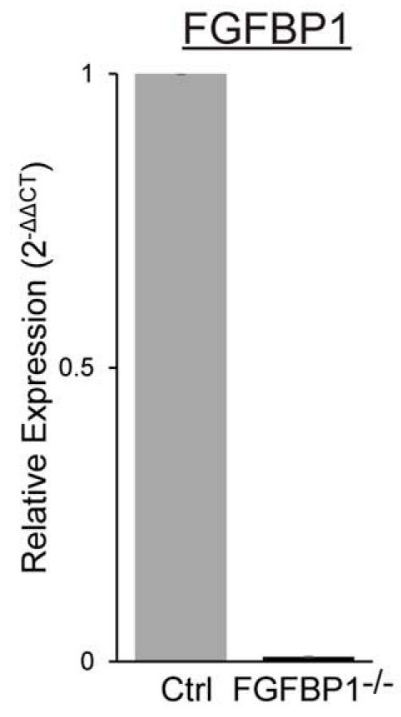

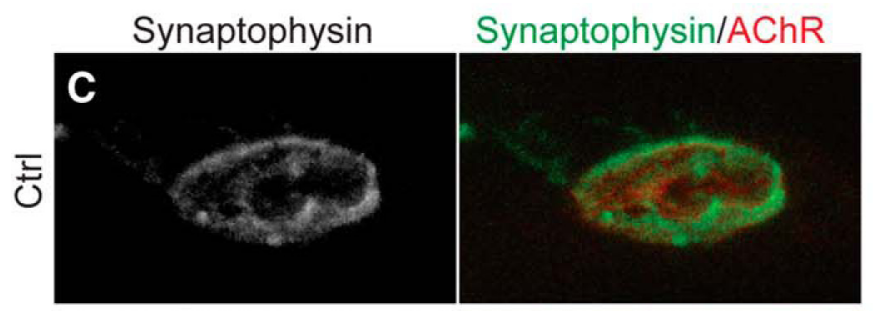

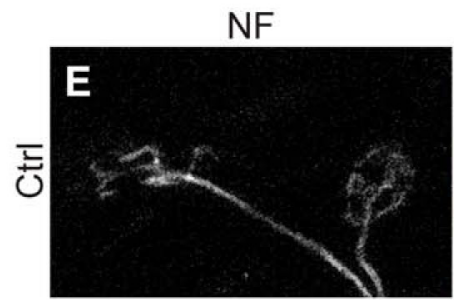

NF/AChRs
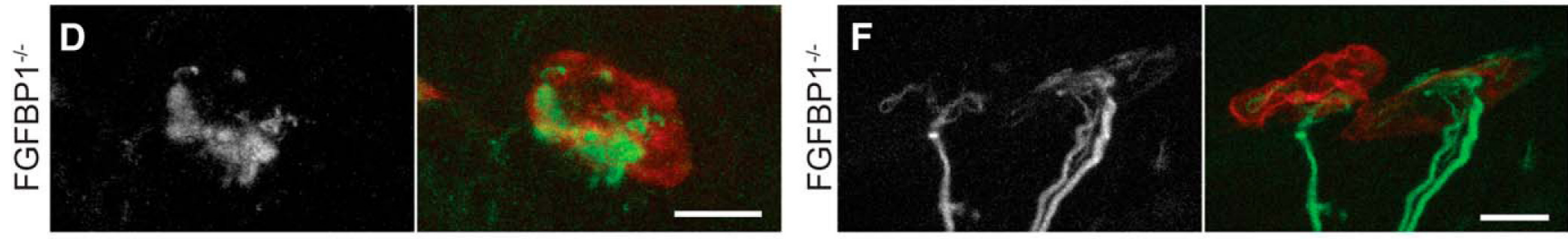

G

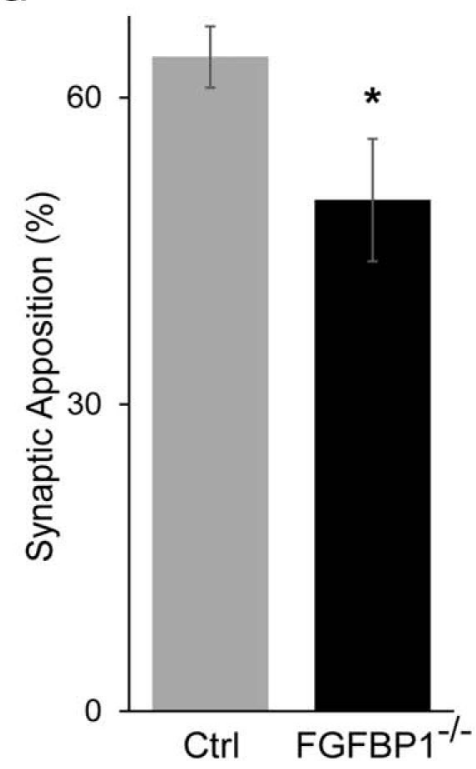

H

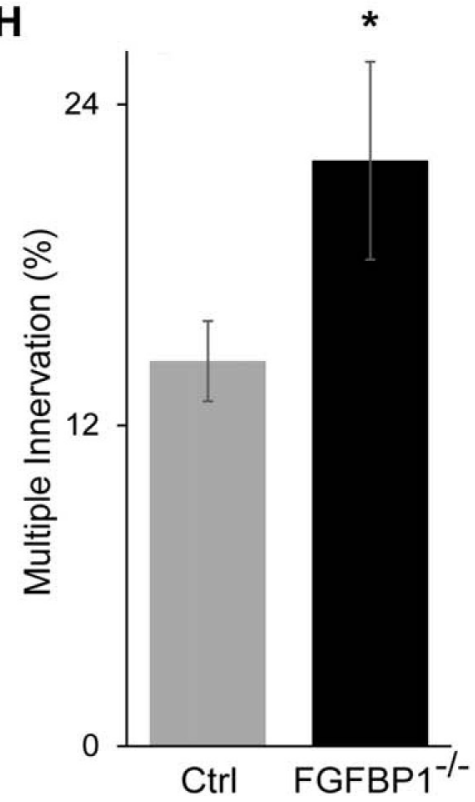

I

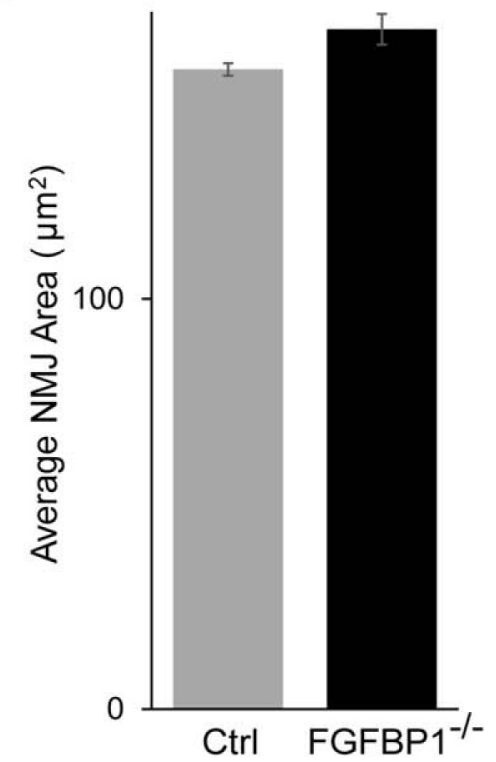

Figure 2. Loss of FGFBP1 delays NMI maturation. A, FGFBP1 Southern blot of electroporated 12955 (Lex2) ES cells shows deletion of the FGFBP1 coding region in clone 2 G4* selected from targeted ES cells. $\boldsymbol{B}$, FGFBP1 mRNA is not detected by qPCR in FGFBP1 ${ }^{-1-}$ mice $(n=1)$. $\boldsymbol{C}-\boldsymbol{F}$, Analysis of NMJs at P8 shows that presynaptic and postsynaptic sites are less apposed $(\mathbf{G}, n=3$, unpaired $t$ test: $\left.{ }^{*} p<0.05\right)$ and more axons are found innervating the same NMJ $\left(H, n=3\right.$, unpaired $t$ test: $\left.{ }^{*} p<0.05\right)$ in FGFBP1 ${ }^{-1-}$ mice compared with controls. I, Loss of FGFBP1 does not affect the size of NMJs $(n=3$, unpaired $t$ test). Scale bar, $20 \mu \mathrm{m}$. Values are reported as mean \pm SEM. NF, Neurofilament. 

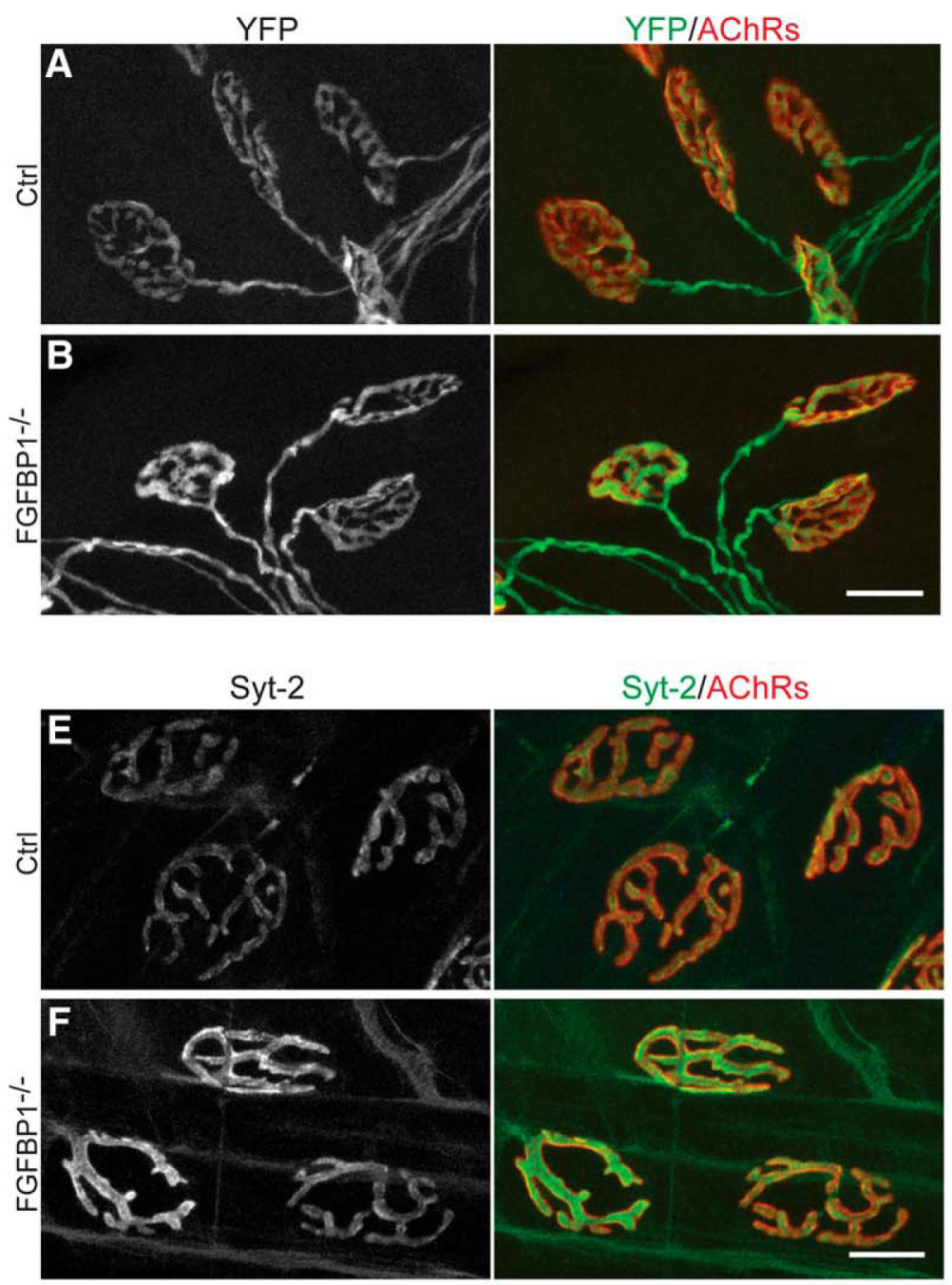
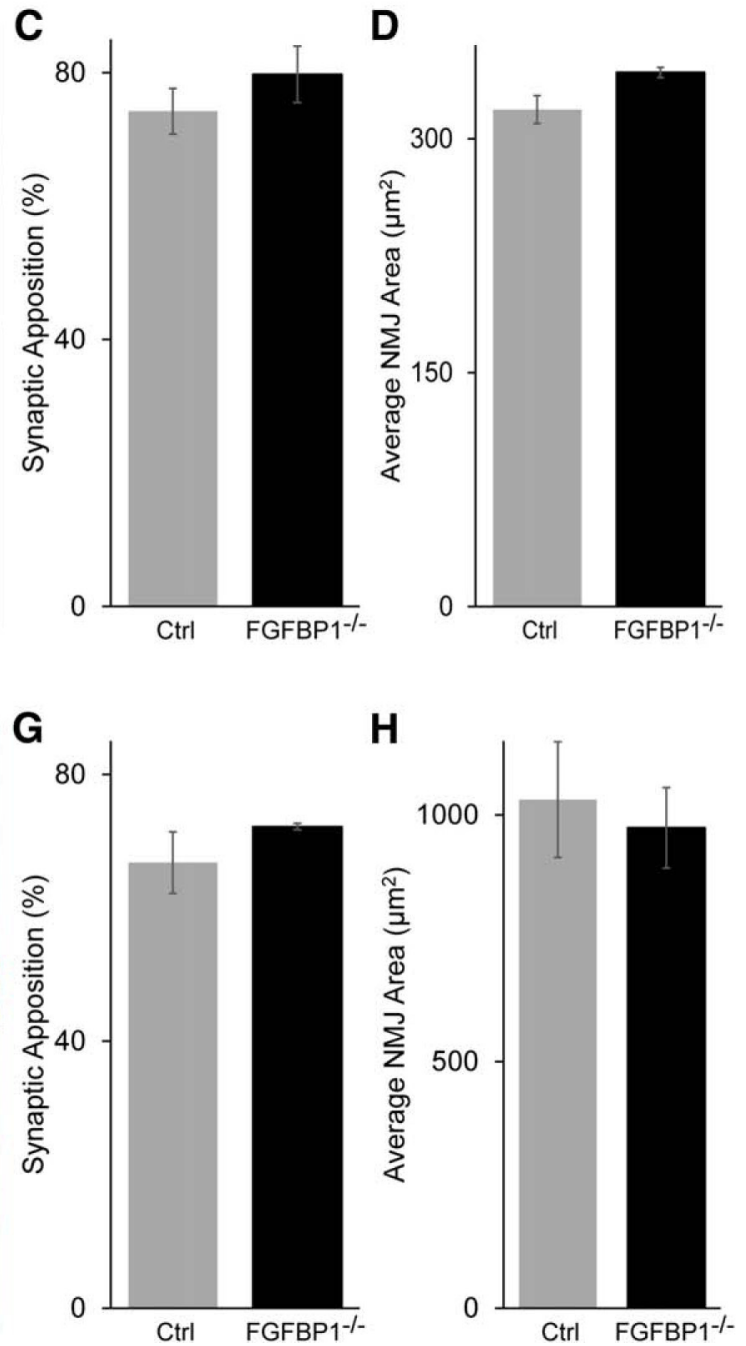

Figure 3. Analysis of NMJs in juvenile and young adult FGFBP1 ${ }^{-1-}$ mice. $A, B, N M J$ analysis in the EDL muscle of P16 mice expressing YFP in motor axons shows no difference in the apposition of the presynaptic and postsynaptic sites $(\boldsymbol{C})$ or size $(\boldsymbol{D})$ of NMJs in FGFBP1 ${ }^{-/-}$mice at P16 compared with those in control mice of the same age $(n=3$, unpaired $t$ test). $\boldsymbol{E}, \boldsymbol{F}$, Analysis of motor axon nerve endings labeled with synaptotagmin-2 (Syt-2) in the EDL of P45 mice. No differences are observed in the apposition of the presynaptic and postsynaptic sites ( $\boldsymbol{G})$ or size $(\boldsymbol{H})$ of NMJs in FGFBP1 ${ }^{-1-}$ mice at P45 compared with those in control mice of the same age ( $n=3$, unpaired $t$ test). Values are reported as mean \pm SEM. Scale bar, $20 \mu \mathrm{m}$.

ingly, loss of FGFBP1 accelerated death of female and male SOD $1^{\mathrm{G} 93 \mathrm{~A}}$ mice (Fig. $4 F-H$ ). Mean survival ages for SOD $1^{\mathrm{G} 93 \mathrm{~A}}$ versus SOD1 ${ }^{\mathrm{G} 93 \mathrm{~A}} ; \mathrm{FGFBP} 1^{-/-}$were, respectively, 146 and $134 \mathrm{~d}$ for males, 155 and $145 \mathrm{~d}$ for females, and 151 and $138 \mathrm{~d}$ for males and females combined. These findings demonstrate that FGFBP1 is required to slow degeneration of motor axon nerve endings at NMJs, thus playing a critical role in the progression of ALSrelated pathogenesis in a mouse model for the disease.

\section{Loss of FGFBP1 accelerates aging of NMJs}

We next explored the possibility that FGFBP1 decreases in skeletal muscles of wild-type mice during aging, contributing to agerelated deleterious structural changes at NMJs. We examined FGFBP1 levels in the TA muscle of 3-, 12-, and 24 month-old wild-type mice. We found an age-related decrease in FGFBP1 transcripts in the TA muscle, where expression was significantly decreased in 24-month-old mice compared with 3-month-old mice (Fig. 5A). Interestingly, aging resulted in reduced expression of FGFBP1 preferentially in the muscle synaptic region. In stark contrast to 3 -month-old mice (Fig. 1D), FGFBP1 is reduced in the synaptic compared with nonsynaptic region of the dia- phragm muscle of 9-month-old mice (Fig. 5B). To assess whether decreased expression of FGFBP1 contributes to age-related changes at NMJ, we examined NMJs in EDL muscles of 12month-old FGFBP1 ${ }^{-1-}$ and control mice expressing YFP in motor axons. We found a significant increase in the number of fragmented NMJs in 12-month-old FGFBP1 ${ }^{-1-}$ compared with control mice of the same sex (Fig. 5C-E). Surprisingly, we found no difference in the number of denervated NMJs between FGFBP $1^{-1-}$ and control mice (Fig. $5 F$ ).

The increased fragmentation of NMJs in FGFBP $1^{-/-}$mice suggested that loss of FGFBP1 might affect expression of molecules with critical roles at NMJs and throughout muscle fibers. To explore this possibility, we first examined transcripts for the gamma and epsilon AChR subunits and MuSK in 12month-old FGFBP $1^{-1-}$ and control mice (Fig. 5G-I). These molecules are enriched in the postsynaptic region and play important roles in the function and maintenance of NMJs. The gamma and epsilon subunits are significantly increased in the TA muscle of FGFBP1 ${ }^{-/-}$compared with control mice (Fig. 5G,H). We then examined levels of the forkhead box protein $\mathrm{O} 1$ and $\mathrm{O} 3$ (FoxO1 and FoxO3), genes that are up- 
A
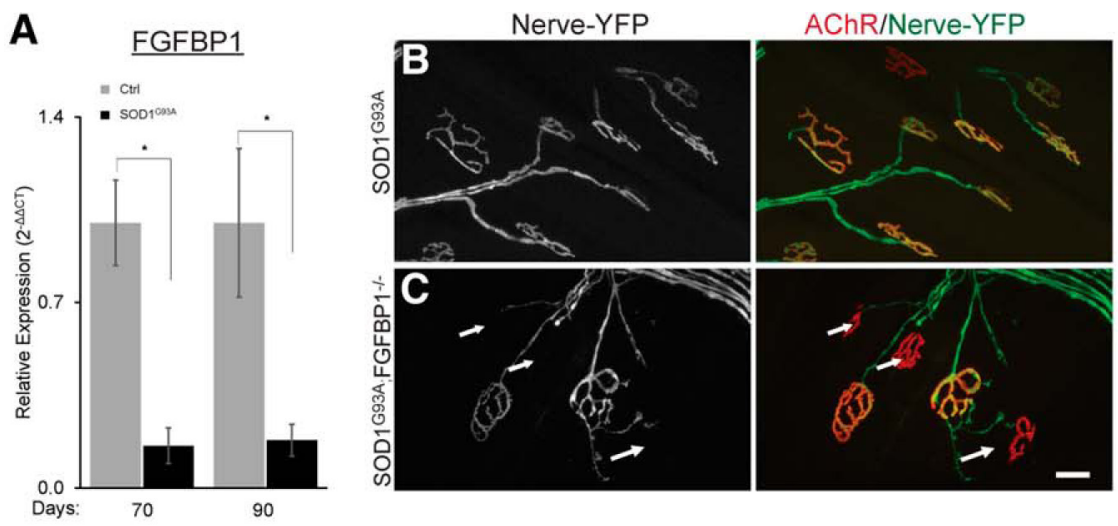

$\mathbf{F}$

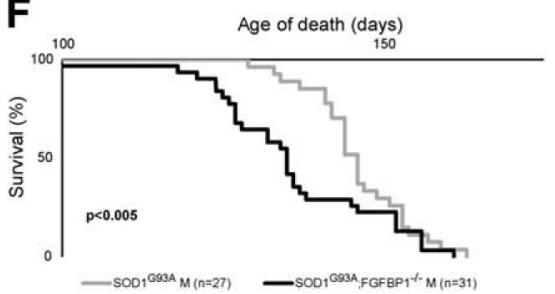

G

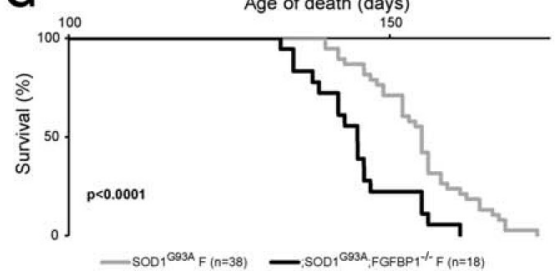

D

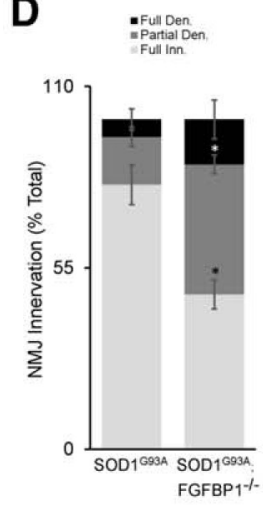

E

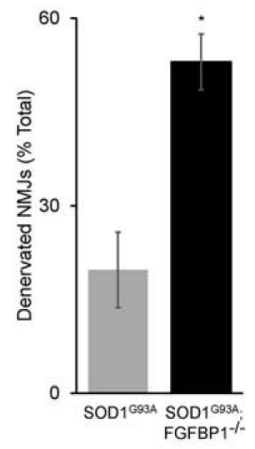

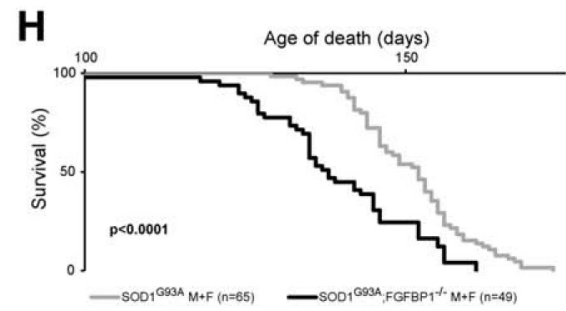

Figure 4. Loss of FGFBP1 accelerates ALS-related pathogenesis in SOD1 ${ }^{\mathrm{G} 93 \mathrm{~A}}$ mice. $A$, FGFBP1 mRNA levels are reduced in TA muscles isolated from presymptomatic (70-d-old) and early symptomatic (90-d-old) SOD $1^{\text {G93A }}$ mice $\left(n \geq 4\right.$, unpaired $t$ test: ${ }^{*} p<0.05$ ). $\boldsymbol{B}-\boldsymbol{E}$, The incidence of partially and fully denervated NMJs is higher in the EDL muscle of $90-d-0$ ld SOD ${ }^{\mathrm{G} 93 \mathrm{~A}}$;FGFBP1 ${ }^{-1-}$ mice compared with SOD1 ${ }^{\mathrm{G} 93 \mathrm{~A}}$ mice expressing FGFBP1. Arrows indicate areas of NMJ denervation ( $n \geq 3$, unpaired $t$ test: $\left.{ }^{*} p<0.05\right)$. F-H, Survival analysis of SOD $1^{\mathrm{G} 93 \mathrm{~A}}$ and SOD1 ${ }^{\mathrm{G93A}}$;FGFBP1 ${ }^{-/-}$ mice shows accelerated death of SOD1 ${ }^{\mathrm{G} 93 \mathrm{~A}}$ mice lacking FGFBP1 $(\boldsymbol{F}$, males, $n=27-31 ; \boldsymbol{G}$, females, $n=18-38 ; \boldsymbol{H}$, males plus females, $n=49-65 ;$ log-rank test). Values are reported as mean \pm SEM. Scale bar, $20 \mu \mathrm{m}$.

regulated in atrophying muscle fibers and function to increase degeneration of muscle fibers (Gomes et al., 2001; Sandri et al., 2004; Fig. 5J-K). We found FoxO3 significantly elevated in the TA muscle of 12-month-old FGFBP $1^{-/-}$mice compared with control mice (Fig. $5 \mathrm{~K}$ ). These findings further indicate that loss of FGFBP1 disrupts the structural and molecular integrity of NMJs and results in pathological changes in muscle fibers during normal aging.

\section{TGF- $\beta 1$ suppresses FGFBP1 expression in muscles}

The data above suggest that preventing loss of endogenous FGFBP1 may slow degeneration of NMJs during aging and in animals harboring mutant genes that cause ALS. Unfortunately, the molecular mechanism that regulates FGFBP1 expression in skeletal muscles and their synaptic region has not been elucidated. The reduced expression of FGFBP1 during development and aging and in SOD1 ${ }^{\text {G93A }}$ mice suggested that nerve-derived factors with important roles at stabilizing the NMJ may affect expression of FGFBP1. ACh and z-agrin are two nerve-derived factors required for the formation, function, and stability of NMJs. We thus investigated whether these two factors affect the expression of FGFBP1. For this, we used the myogenic cell line $\mathrm{C} 2 \mathrm{C} 12$. After fusion, C2C12-derived myotubes depolarize in the presence of $\mathrm{ACh}$ and respond to $\mathrm{z}$-agrin by forming postsynaptic-like structures that include nAChRs. First, we ascertained that C2C12 cells express FGFBP1. We found FGFBP1 expressed at higher levels in myotubes compared with unfused proliferating $\mathrm{C} 2 \mathrm{C} 12$ cells (Fig. $6 A$ ), supporting our ribosomal profiling data showing that muscle fibers express FGFBP1 in mice. We then investigated whether cholinergic transmission using carbachol, an ACh mimetic, or recombinant z-agrin affect levels of FGFBP1 in myotubes. We found FGFBP1 expressed at similar levels in myotubes treated for $24 \mathrm{~h}$ with carbachol (Fig.
6B), z-agrin (Fig. 6C), and vehicle. These findings indicate that neither cholinergic transmission nor z-agrin affects the levels of FGFBP1 expression in skeletal muscles.

We next investigated whether TGF- $\beta 1$ suppresses FGFBP1 expression in skeletal muscles. We focused on TGF- $\beta 1$ because it has been shown to repress FGFBP1 expression in mesenchymal and neural crest cells as they differentiate into smooth muscles (Briones et al., 2006). To determine whether TGF- $\beta 1$ inhibits FGFBP1 expression, we treated C2C12-derived myotubes with TGF- $\beta 1$ alone and together with SB-431542, a small synthetic molecule that inhibits the TGF- $\beta$ type I receptor. In myotubes treated with TGF- $\beta 1$ alone for $24 \mathrm{~h}$, FGFBP1 expression was reduced compared with vehicle-treated myotubes (Fig. 6D). In the presence of SB-431542, however, TGF- $\beta 1$ was unable to repress FGFBP1 effectively (Fig. 6D). This finding, together with the lack of myotube atrophy in the presence of TGF- $\beta 1$ (Fig. $6 E, F)$ assessed by measuring their diameter at the widest region after staining for myosin heavy chain using the MF20 antibody, indicates that TGF- $\beta 1$-initiated signaling inhibits FGFBP1 expression in cultured myotubes.

\section{TGF- $\beta 1$ is elevated in developing, aged, and diseased} skeletal muscles

The finding that TGF- $\beta 1$ suppresses FGFBP1 in myotubes indicates that levels of these molecules may be inversely correlated in vivo. To test this possibility, we examined transcripts for the three TGF- $\beta$ isoforms (TGF- $\beta 1$, TGF- $\beta 2$, and TGF- $\beta 3$ ) in skeletal muscles from developing, aged, and SOD $1^{\mathrm{G} 93 \mathrm{~A}}$ mice. We found all three TGF- $\beta$ isoforms significantly increased in the TA muscle of developing compared with young adult mice (Fig. 7A). A similar pattern of TGF- $\beta$ upregulation was observed in the TA muscle of aged mice (Fig. $7 B$ ), in which TGF- $\beta 2$ displayed the greatest increase in expression, whereas TGF- $\beta 1$ was only modestly in- 
A

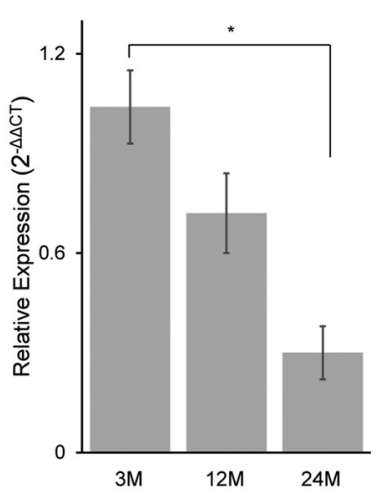

B

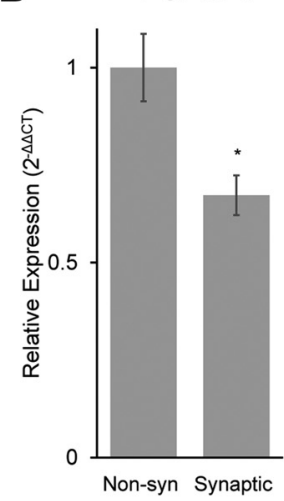

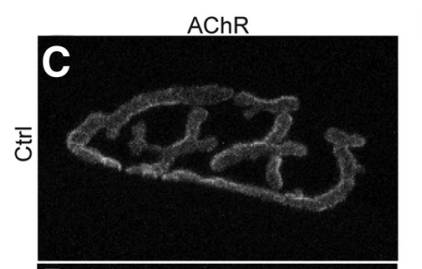

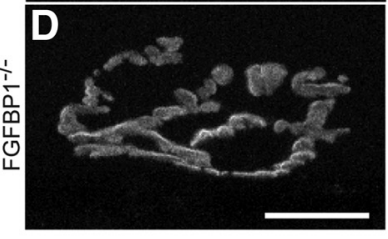

E

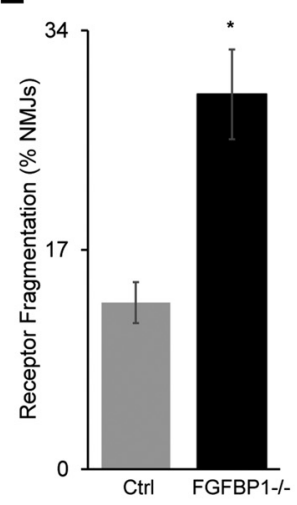

$\mathbf{F}$

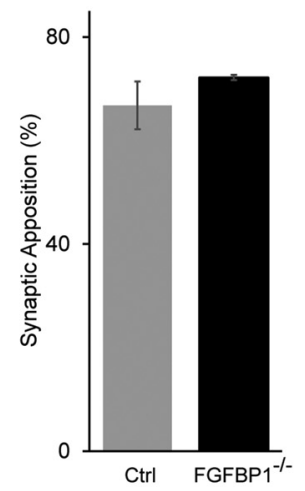

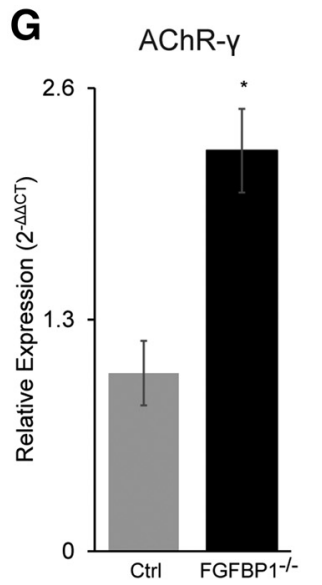
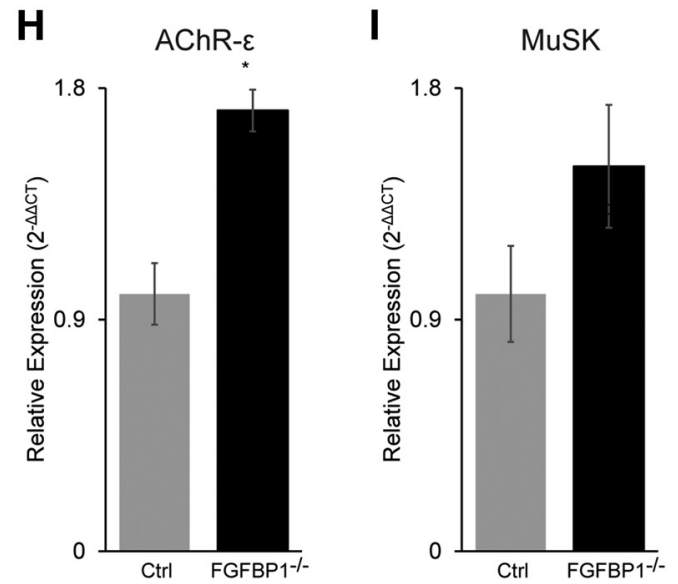

J

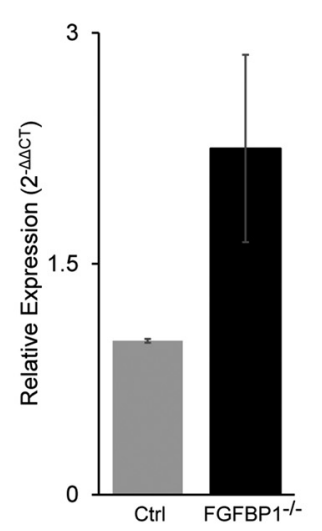

K

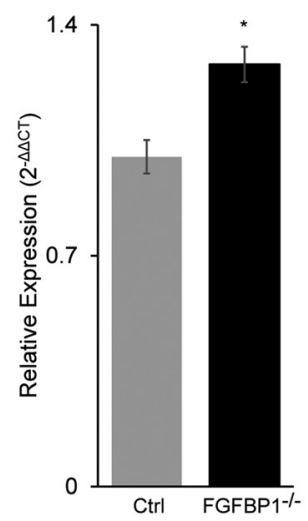

Figure 5. Loss of FGFBP1 accelerates aging of NMJs. A, FGFBP1 mRNA is reduced in the TA muscle of 12-month-old (12M) and 24-month-old (24M) mice compared with 3-month-old (3M) mice $\left(n=3\right.$, one-way ANOVA followed by Bonferroni post hoc analysis: $\left.{ }^{*} p<0.05\right)$. B, In the diaphragm muscle of 9-month-old mice, FGFBP1 expression is lower in the synaptic compared with nonsynaptic region $\left(n=3\right.$, unpaired $t$ test: $\left.{ }^{*} p<0.05\right)$. C $\boldsymbol{E}$, Incidence of fragmented NMJs is higher in 12 -month-old FGFBP $1^{-1-}$ mice compared with control mice $\left(n \geq 4\right.$, unpaired $t$ test: ${ }^{*} p<$ 0.05). $\boldsymbol{F}$, Presynaptic and postsynaptic sites of the NMJ are similarly apposed in 12 -month-old control and FGFBP $1^{-1-}$ mice $(n=3$, unpaired $t$ test $)$. G-I, Genes associated with the NMJs, including AChR- $\gamma\left(\mathbf{G}, n=3\right.$, unpaired $t$ test: $\left.{ }^{*} p<0.05\right)$, AChR-epsilon $\left(\boldsymbol{H}, n=3\right.$, unpaired $t$ test: $\left.{ }^{*} p<0.05\right)$, and MuSK $\left(I, n=3\right.$, unpaired $t$ test), are increased in the TA muscle of 12 -month-old FGFBP1 ${ }^{-I-}$ mice compared with controls. $\boldsymbol{J}, \boldsymbol{K}$, Evaluation of genes associated with muscle atrophy including Fox $01(\boldsymbol{J}, n=3$, unpaired $t$ test $)$ and Fox $03\left(\boldsymbol{K}, n=3\right.$, unpaired $t$ test: $\left.{ }^{*} p<0.05\right)$ in the TA muscle of 12-month-old FGFBP1 ${ }^{-1-}$ mice compared with controls. Values are reported as mean \pm SEM. Scale bar, $20 \mu \mathrm{m}$.

creased. We next assessed TGF- $\beta$ levels in SOD $1^{\text {G93A }}$ mice. As in developing muscles, we found significant increases in all three TGF- $\beta$ isoforms, particularly TGF- $\beta 1$, in both presymptomatic (Fig. $8 A$ ) and early symptomatic (Fig. $8 B$ ) SOD $1^{\text {G93A }}$ mice. These findings show that TGF- $\beta$ increases in skeletal muscles under conditions that result in lower levels of FGFBP1 and dramatic structural changes at NMJs.

TGF- $\beta 1$ concentrates specifically at NMJs of SOD1 ${ }^{\mathrm{G} 93 \mathrm{~A}}$ mice Finally, we investigated whether TGF- $\beta 1$ localizes to and accumulates at NMJs, thereby potentially having a local effect on FGFBP1 levels. For this, we stained $16 \mu \mathrm{m}$ cross-sections of the TA muscle from wild-type developing, young adult and aged mice with an antibody against TGF- $\beta 1$. We also stained TA muscles from 90 -d-old early symptomatic SOD ${ }^{\text {G93A }}$ mice. To locate NMJs, muscle sections were stained with fBTX. This experiment revealed that TGF- $\beta 1$ is present, albeit at low levels, at most NMJs in young adult wild-type animals (Fig. 7D). However, we found no appreciable difference in TGF- $\beta 1$ at NMJs of developing and old mice compared young adult mice (Fig. $7 C-E$ ). In stark contrast, TGF- $\beta 1$ was significantly increased at NMJs of 90 -d-old SOD1 ${ }^{\text {G93A }}$ mice compared with
NMJs from wild-type mice of the same age and sex (Fig. 8C$E$ ). The high and select accumulation of TGF- $\beta 1$ at NMJs of SOD $1^{\mathrm{G} 93 \mathrm{~A}}$ mice could explain the acute reduction of FGFBP1 in SOD $1^{\mathrm{G} 93 \mathrm{~A}}$ mice compared with developing and old mice. It also suggests that TGF- $\beta 1$ might contribute directly to the destruction of NMJs in SOD $1^{\mathrm{G} 93 \mathrm{~A}}$ mice.

\section{Discussion}

In recent years, it has become evident that molecules involved in the initial formation of NMJs (Sanes and Lichtman, 1999, 2001; Koles and Budnik, 2012; Valdez et al., 2014) are required for its maintenance and repair in adulthood. For example, we now know that nerve-derived agrin (Glass et al., 1996) and its receptor, LRP4 (Kim et al., 2008), are necessary for the maintenance of the postsynaptic apparatus in young adult mice (Samuel et al., 2012; Barik et al., 2014). Likewise, muscle fibers must continuously secrete factors to maintain the presynapse and thus the NMJ (McCann et al., 2007). However, the identity of these muscle-derived factors has remained elusive. Here, we show that muscle fibers secrete FGFBP1 to slow degeneration of NMJs during aging and in a mouse model for ALS. However, FGFBP1 expression decreases as skeletal mus- 
A

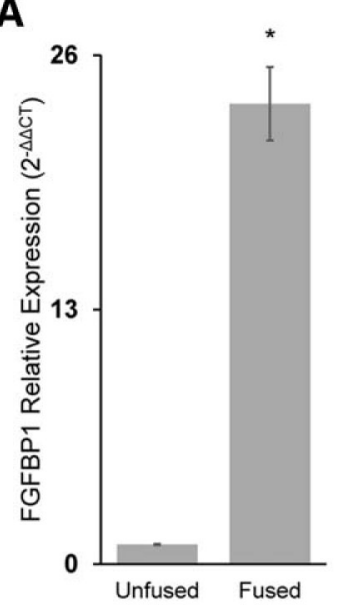

C
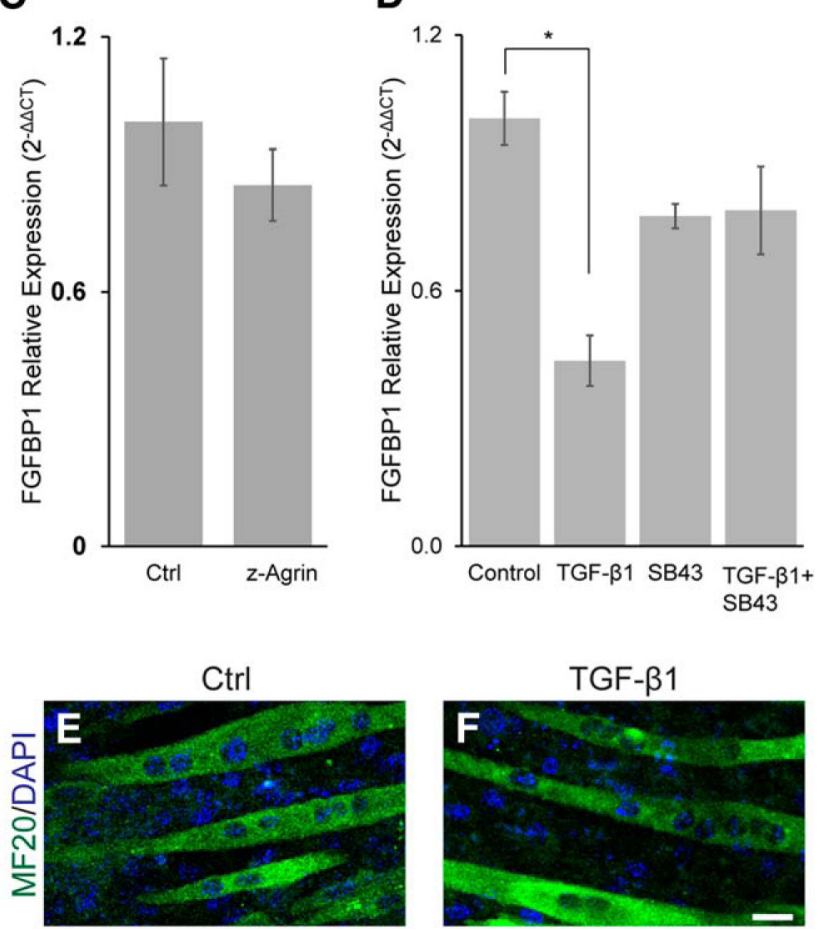

B

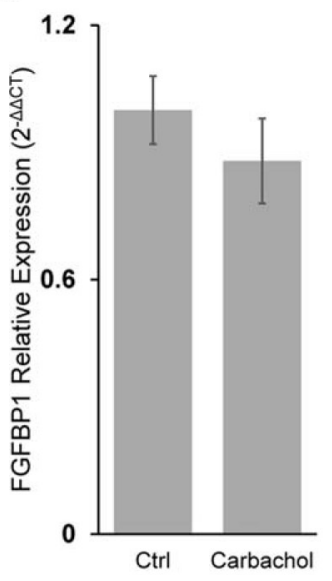

muscles and innervating motor axons. Deletion of the FGFR2b receptor, which is present in motor neurons, was found to delay presynaptic differentiation of developing motor axons (Fox et al., 2007). This receptor is activated by FGF-7/10/22, three ligands shown to play roles at synapses (Umemori, 2009; Williams et al., 2009; Terauchi et al., 2010) and to be expressed in skeletal muscles. Therefore, FGFBP1 may affect the NMJ by enhancing the biological activity of FGF-7/10/22. However, FGFBP1 also binds and enhances the biological activity of FGF-1 and FGF-2 (Tassi et al., 2007), both implicated in axonal regeneration (Walter et al., 1993; Kim et al., 2003; Tassi et al., 2007) and muscle biogenesis (Hannon et al., 1996; Husmann et al., 1996; Sheehan and Allen, 1999; Kästner et al., 2000). Therefore, it is plausible that loss of FGFBP1 causes other cellular changes in skeletal muscles that in turn affect the NMJ. A recent report showed that FGFBP1 is induced in skeletal muscle in a mouse model for spinal muscular atrophy (Valsecchi et al., 2015), presumably to stave off muscle and axonal degeneration. Nonetheless, the following data strongly suggest direct roles for FGFBP1 at NMJs: (1) FGFBP1 concentrates at NMJs; (2) FGFBP1 is preferentially reduced in the synaptic region of aged muscles; (3) loss of FGFBP1 results in structural and molecular changes at NMJs of aged mice; and (4) loss of FGFBP1 accelerates muscle denervation in SOD1 $1^{\mathrm{G} 93 \mathrm{~A}}$ mice, a mouse model for ALS that is characterized by early and progressive degeneration of the NMJ. We therefore conclude that muscle fibers secrete FGFBP1 to maintain the structural integrity of NMJs.

\section{TGF- $\boldsymbol{\beta}$ pathway suppresses FGFBP1 expression in}

\section{skeletal muscles}

We showed that TGF- $\beta 1$ inhibits FGFBP1 expression in skeletal muscles. This finding is consistent with published data showing that TGF- $\beta 1$ represses FGFBP1 expression in mesenchymal and neural crest cells as they differentiate into smooth muscles (Briones et al., 2006). Our data and published findings also show that all three TGF- $\beta$ isoforms are elevated in developing, aged, and disease-afflicted skeletal muscles before and as NMJs undergo structural changes (Carlson et al., 2008; Si et al., 2015). These findings suggest that reducing TGF- $\beta$ ligands may restore normal levels of endogenous FGFBP1 in aged and disease-afflicted skeletal muscles and possibly halt the degeneration of NMJs. However, TGF- $\beta$ ligands are expressed ubiquitously and have pleiotropic effects that include promoting the maturation of the NMJ and synapses in the CNS, axonal regeneration, and muscle atrophy (Sanyal et al., 2004; Feng and Ko, 2008; Burks and Cohn, 2011; Mendias et al., 2012). Therefore, tampering with TGF- $\beta$ levels is likely to have many off-target effects in animals. It would therefore be more desirable to target downstream effectors of TGF- $\beta$ ligands responsible for suppressing FGFBP1 in skeletal muscles. There are several TGF- $\beta$ effectors in skeletal muscles that could affect FGFBP1 expression. These include transcriptional modulators such as Sox12 (Huang et al., 2015), Krüppel-like factor 5 and 15 (Zheng et al., 2009; Morrison-Nozik et al., 2015), transcription factor 4 (Ray et al., 2003), hypermethylation in cancer-1 (Hic-1; Briones et al., 2006), and the AP1 and CCAAT/enhancer-binding proteins (Harris et al., 2001). In addition to FGFBP1, downstream targets of TGF- $\beta 1$ likely affect levels of additional genes with important functions in muscle fibers, motor axons, and perisynaptic Schwann cells. Therefore, TGF- $\beta$ effectors responsible for suppressing

Linking FGFBP1 to FGF ligands with roles in synaptic development and muscle biogenesis

The biological effects of FGFBP1 (Tassi et al., 2001) depend on the types of FGF ligands and cognate receptors present in skeletal cles undergo pathophysiological changes and our data suggest that this decrease contributes to age- and disease-related changes at NMJs. We also provide evidence indicating that TGF- $\beta 1$, known to cause muscle atrophy (Burks and Cohn, 2011), suppresses FGFBP1 expression.

Figure 6. TGF- $\beta 1$ inhibits FGFBP1 expression in myotubes. The effect of cholinergic activity, $z$-agrin, and TGF- $\beta 1$ on FGFBP1 expression was examined in myotubes derived the presence of TGF- $\beta 1$ (10 $\mathrm{ng} / \mathrm{ml})$ for $24 \mathrm{~h}$. Values are reported as mean \pm SEM. Scale 
A

Development

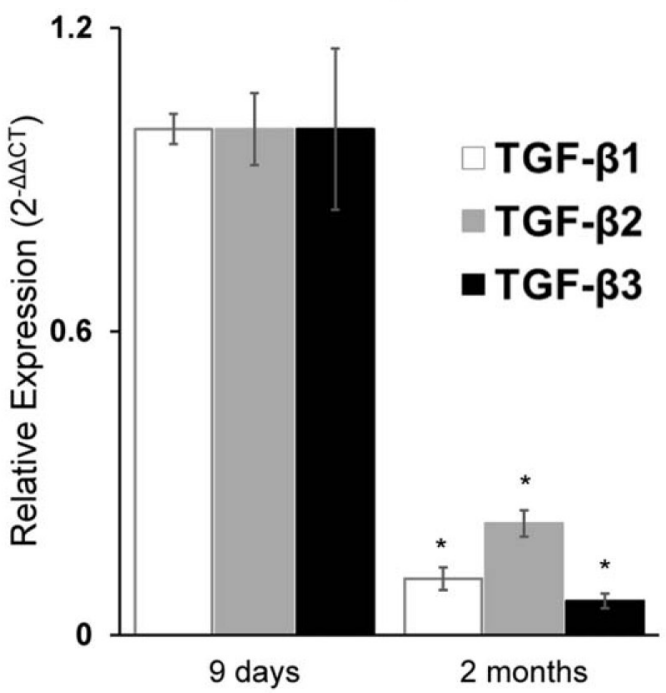

B

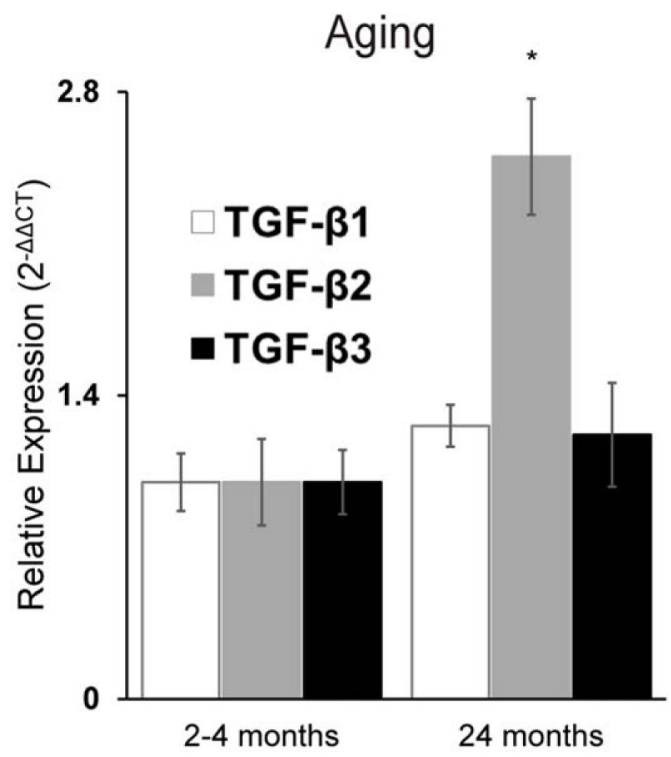

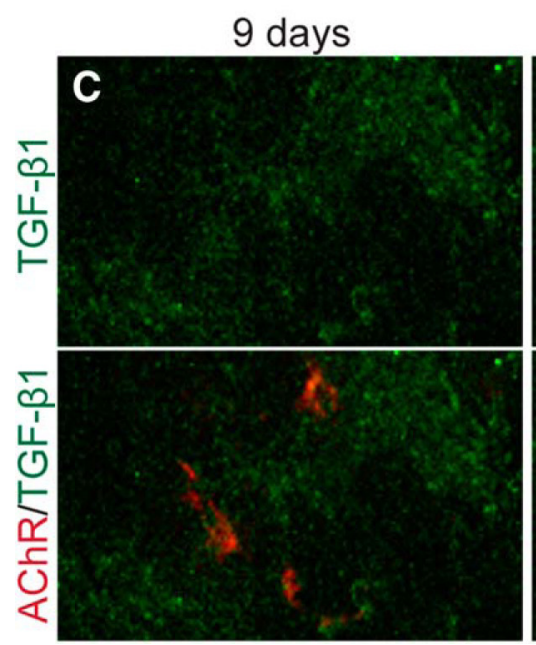
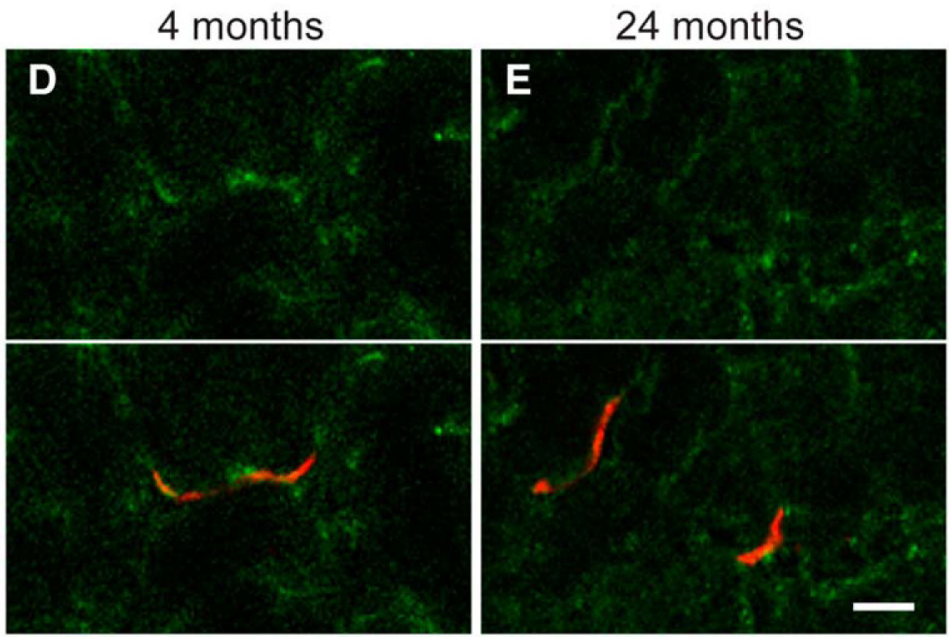

Figure 7. Analysis of TGF- $\beta$ expression and distribution in developing and aged skeletal muscles. $A$, Transcripts of all 3 TGF- $\beta$ isoforms are expressed at higher levels in developing compared with young adult TA muscles $\left(n=3\right.$, unpaired $t$ test: $\left.{ }^{*} p<0.05\right)$. B, TGF- $\beta 2$ is significantly elevated in aged TA muscle, whereas TGF- $\beta 1$ and TGF- $\beta 2$ are only modestly increased compared with young adult $(n=5$, unpaired $t$ test: $*<0.05)$. $C-E$, Immunostaining for TGF- $\beta 1$ revealed similar levels in synaptic and nonsynaptic regions of developing, adult, and aged TA muscles. Values are reported as mean \pm SEM. Scale bar, $10 \mu \mathrm{m}$.

FGFBP1 expression in skeletal muscles might be therapeutic targets for preventing degeneration of aging and diseaseafflicted NMJs.

\section{TGF- $\beta$ effect on FGFBP1 expression at the NMJ}

Our data also suggest that the TGF- $\beta$ pathway might inhibit FGFBP1 expression preferentially in myonuclei associated with the NMJ in SOD $1^{\text {G93A }}$ mice. We base this hypothesis on our own and published data. We show that TGF- $\beta 1$ is increased at NMJs of SOD $1^{\text {G93A }}$ mice but unchanged at NMJs of developing and aged mice. Recently, it was reported that TGF- $\beta 1$ inhibits expression of miR-206, a microRNA concentrated at the NMJ, leading to increased expression of its target, histone deacetylase 4 (HDAC4), in skeletal muscles (Winbanks et al., 2011). These two factors have been shown to alter FGFBP1 levels in stressed skeletal muscles and contribute to the degeneration of NMJs in SOD $1^{\text {G93A }}$ mice (Williams et al., 2009). We thus propose that TGF- $\beta 1$ inhibits miR-206 pref- erentially and concurrently increases HDAC4 expression in myonuclei associated with the $\mathrm{NMJ}$ in $\mathrm{SOD} 1^{\mathrm{G} 93 \mathrm{~A}}$ mice. HDAC4 then interacts with Hic-1, a TGF- $\beta 1$ effector, and together they repress FGFBP1 expression preferentially at myonuclei located at the NMJ.

\section{Significance of TGF- $\beta 1$ accumulation at NMJs of SOD $1^{\text {G93A }}$ mice}

Accumulating data suggest that heightened TGF- $\beta 1$ levels contribute to ALS-related pathologies in SOD1 ${ }^{\mathrm{G} 93 \mathrm{~A}}$ mice (Endo et al., 2015; Si et al., 2015). Specifically, it was shown recently that increased expression of TGF- $\beta 1$ in astrocytes, cells with critical roles at synapses in the CNS, accelerates ALS-like symptoms and death of SOD $1^{\mathrm{G} 93 \mathrm{~A}}$ mice (Endo et al., 2015). In this study, we show that TGF- $\beta 1$ is increased at NMJs of SOD $1^{\text {G93A }}$ mice. These findings raise the possibility that TGF- $\beta 1$ promotes synaptic degeneration in SOD $1^{\text {G93A }}$ mice. At the NMJ, TGF- $\beta 1$ might act by reducing levels of 

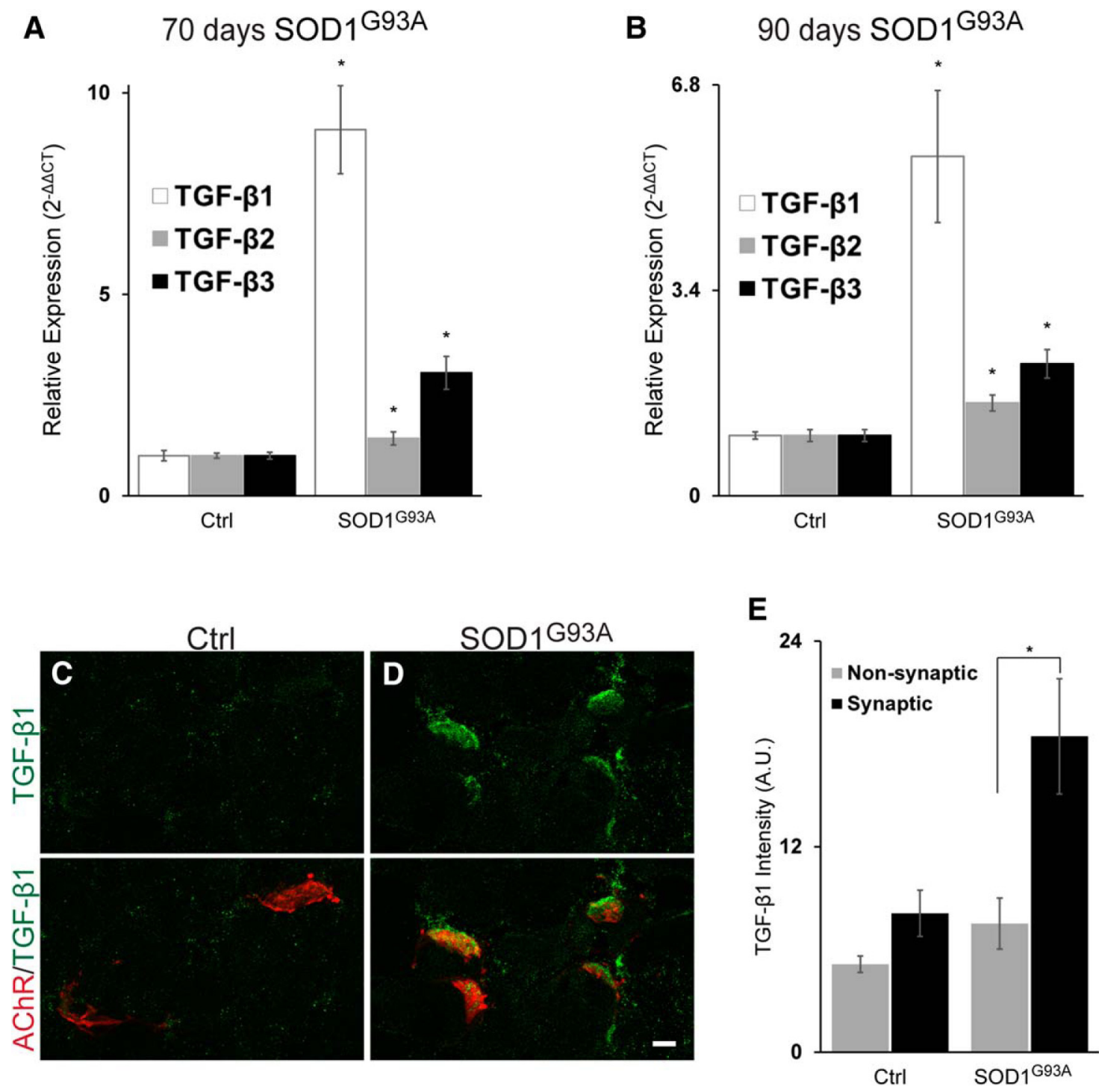

Figure 8. TGF- $\beta 1$ is elevated in ALS-afflicted skeletal muscles and NMJs. TGF- $\beta$ isoforms are significantly increased in the TA muscle of presymptomatic $\left(\boldsymbol{A}, n=4\right.$, unpaired $t$ test: $\left.{ }^{*} p<0.05\right)$ and early symptomatic $\left(\boldsymbol{B}, n=4\right.$, unpaired $t$ test: $\left.{ }^{*} p<0.05\right)$ SOD $1^{693 A}$ mice. $\boldsymbol{C}-\boldsymbol{E}$, TGF- $\beta 1$ is significantly increased at NMJs of the TA muscle from 90 -d-old SOD ${ }^{693 \mathrm{~A}}$ mice $(n=3$, unpaired $t$ test: $\left.{ }^{*} p<0.05\right)$. Values are reported as mean \pm SEM. Scale bar, $10 \mu \mathrm{m}$.

miR-206 and FGFBP1, both localized and required to slow degeneration of motor axons innervating muscle fibers in SOD $1^{\mathrm{G} 93 \mathrm{~A}}$ mice. In contrast to SOD $1^{\mathrm{G} 93 \mathrm{~A}}$ mice, motor axons and the postsynaptic region of the NMJ remain highly plastic in developing and aged mice, in which TGF- $\beta 1$ is not elevated despite its overall increase in skeletal muscles compared with young adult mice. Therefore, our findings strongly suggest that the location of TGF- $\beta 1$ might determine its biological effects on skeletal muscles, motor axons, and their NMJs. Our data also suggest that TGF- $\beta 1$ might be secreted by specific cells within skeletal muscles, accounting for its differential distribution in developing, aged, and SOD ${ }^{\text {G93A }}$ mice. Perisynaptic Schwan cells (PSCs) might contribute much of the TGF- $\beta 1$ concentrated at the NMJ of SOD $1^{\text {G93A }}$ mice. Similar to astrocytes, Schwann cells increase expression of TGF- $\beta 1$ upon activation (Mews and Meyer, 1993; Einheber et al., 1995; Griffin and Thompson, 2008). Because PSCs are hyperactivated in presymptomatic SOD $1{ }^{\mathrm{G} 93 \mathrm{~A}}$ mice, it is reasonable to hypothesize that they contribute to the increased levels of TGF- $\beta 1$ found at the NMJ synaptic cleft.
Future directions and therapeutic potentials of FGFBP1 in skeletal muscles

In conclusion, our data strongly suggest that FGFBP1 and TGF- $\beta 1$ may serve as therapeutic targets for slowing the erosion of motor function due to aging and ALS. There are additional experiments, however, needed to ascertain the sufficiency of FGFBP1 and TGF- $\beta 1$ in slowing and reversing destruction of aging and ALS-afflicted NMJs and skeletal muscles. These include assessing the impact of introducing FGFBP1 into aging and ALS-afflicted skeletal muscles and NMJs. The effect of reducing TGF- $\beta 1$ levels and inhibiting its receptor and downstream targets responsible for FGFBP1 expression would also need to be assessed in aging and ALS-afflicted skeletal muscles and NMJs. Regardless of approach, this study shows that FGFBP1 and TGF- $\beta 1$ are potential targets for preserving the structural integrity of aging and disease-affected NMJs.

\section{References}

Abuharbeid S, Czubayko F, Aigner A (2006) The fibroblast growth factorbinding protein FGF-BP. Int J Biochem Cell Biol 38:1463-1468. CrossRef Medline 
Barik A, Lu Y, Sathyamurthy A, Bowman A, Shen C, Li L, Xiong WC, Mei L (2014) LRP4 is critical for neuromuscular junction maintenance. J Neurosci 34:13892-13905. CrossRef Medline

Bayat V, Jaiswal M, Bellen HJ (2011) The BMP signaling pathway at the Drosophila neuromuscular junction and its links to neurodegenerative diseases. Curr Opin Neurobiol 21:182-188. CrossRef Medline

Beer HD, Bittner M, Niklaus G, Munding C, Max N, Goppelt A, Werner S (2005) The fibroblast growth factor binding protein is a novel interaction partner of FGF-7, FGF-10 and FGF-22 and regulates FGF activity: implications for epithelial repair. Oncogene 24:5269-5277. CrossRef Medline

Bowen DC, Park JS, Bodine S, Stark JL, Valenzuela DM, Stitt TN, Yancopoulos GD, Lindsay RM, Glass DJ, DiStefano PS (1998) Localization and regulation of MuSK at the neuromuscular junction. Dev Biol 199:309319. CrossRef Medline

Briones VR, Chen S, Riegel AT, Lechleider RJ (2006) Mechanism of fibroblast growth factor-binding protein 1 repression by TGF-beta. Biochem Biophys Res Commun 345:595-601. CrossRef Medline

Burkholder TJ, Fingado B, Baron S, Lieber RL (1994) Relationship between muscle fiber types and sizes and muscle architectural properties in the mouse hindlimb. J Morphol 221:177-190. CrossRef Medline

Burks TN, Cohn RD (2011) Role of TGF- $\beta$ signaling in inherited and acquired myopathies. Skelet Muscle 1:19. CrossRef Medline

Cardasis CA, LaFontaine DM 1987 Aging rat neuromuscular junctions: a morphometric study of cholinesterase-stained whole mounts and ultrastructure. Muscle Nerve 10:200-213. Medline

Carlson ME, Hsu M, Conboy IM (2008) Imbalance between pSmad3 and Notch induces CDK inhibitors in old muscle stem cells. Nature 454:528532. CrossRef Medline

Celio MR, Heizmann CW (1982) Calcium-binding protein parvalbumin is associated with fast contracting muscle fibres. Nature 297:504-506. CrossRef Medline

Einheber S, Hannocks MJ, Metz CN, Rifkin DB, Salzer JL (1995) Transforming growth factor-beta 1 regulates axon/Schwann cell interactions. J Cell Biol 129:443-458. CrossRef Medline

Endo F, Komine O, Fujimori-Tonou N, Katsuno M, Jin S, Watanabe S, Sobue G, Dezawa M, Wyss-Coray T, Yamanaka K (2015) Astrocyte-derived TGF- $\beta 1$ accelerates disease progression in ALS mice by interfering with the neuroprotective functions of microglia and T cells. Cell Rep 11:592604. CrossRef Medline

Filézac de L'Etang A, Maharjan N, Cordeiro Braña M, Ruegsegger C, Rehmann R, Goswami A, Roos A, Troost D, Schneider BL, Weis J, Saxena S (2015) Marinesco-Sjögren syndrome protein SIL1 regulates motor neuron subtype-selective ER stress in ALS. Nat Neurosci 18:227-238. CrossRef Medline

Fahim MA, Robbins N (1982) Ultrastructural studies of young and old mouse neuromuscular junctions. J Neurocytol 11:641-656. CrossRef Medline

Fahim MA, Holley JA, Robbins N (1983) Scanning and light microscopic study of age changes at a neuromuscular junction in the mouse. J Neurocytol 12:13-25. CrossRef Medline

Feng G, Mellor RH, Bernstein M, Keller-Peck C, Nguyen QT, Wallace M, Nerbonne JM, Lichtman JW, Sanes JR (2000) Imaging neuronal subsets in transgenic mice expressing multiple spectral variants of GFP. Neuron 28:41-51. CrossRef Medline

Feng Z, Ko CP (2008) Schwann cells promote synaptogenesis at the neuromuscular junction via transforming growth factor-betal. J Neurosci 28: 9599-9609. CrossRef Medline

Fox MA, Sanes JR, Borza DB, Eswarakumar VP, Fässler R, Hudson BG, John SW, Ninomiya Y, Pedchenko V, Pfaff SL, Rheault MN, Sado Y, Segal Y, Werle MJ, Umemori H (2007) Distinct target-derived signals organize formation, maturation, and maintenance of motor nerve terminals. Cell 129:179-193. CrossRef Medline

Glass DJ, Bowen DC, Stitt TN, Radziejewski C, Bruno J, Ryan TE, Gies DR, Shah S, Mattsson K, Burden SJ, DiStefano PS, Valenzuela DM, DeChiara TM, Yancopoulos GD (1996) Agrin acts via a MuSK receptor complex. Cell 85:513-523. CrossRef Medline

Gomes MD, Lecker SH, Jagoe RT, Navon A, Goldberg AL (2001) Atrogin-1, a muscle-specific F-box protein highly expressed during muscle atrophy. Proc Natl Acad Sci U S A 98:14440-14445. CrossRef Medline

Griffin JW, Thompson WJ (2008) Biology and pathology of nonmyelinating schwann cells. Glia 56:1518-1531. CrossRef Medline

Gurney ME, Pu H, Chiu AY, Dal Canto MC, Polchow CY, Alexander DD,
Caliendo J, Hentati A, Kwon YW, Deng HX (1994) Motor neuron degeneration in mice that express a human $\mathrm{Cu}, \mathrm{Zn}$ superoxide dismutase mutation. Science 264:1772-1775. CrossRef Medline

Hannon K, Kudla AJ, McAvoy MJ, Clase KL, Olwin BB (1996) Differentially expressed fibroblast growth factors regulate skeletal muscle development through autocrine and paracrine mechanisms. J Cell Biol 132:1151-1159. CrossRef Medline

Harris VK, Kagan BL, Ray R, Coticchia CM, Liaudet-Coopman ED, Wellstein A, Tate Riegel A (2001) Serum induction of the fibroblast growth factorbinding protein (FGF-BP) is mediated through ERK and p38 MAP kinase activation and C/EBP-regulated transcription. Oncogene 20:1730-1738. CrossRef Medline

Hippenmeyer S, Vrieseling E, Sigrist M, Portmann T, Laengle C, Ladle DR, Arber S (2005) A developmental switch in the response of DRG neurons to ETS transcription factor signaling. PLoS Biol 3:e159. CrossRef Medline

Huang W, Chen Z, Shang X, Tian D, Wang D, Wu K, Fan D, Xia L (2015) Sox12, a direct target of FoxQ1, promotes hepatocellular carcinoma metastasis through up-regulating Twist1 and FGFBP1. Hepatology 61:1920 1933. CrossRef Medline

Husmann I, Soulet L, Gautron J, Martelly I, Barritault D (1996) Growth factors in skeletal muscle regeneration. Cytokine Growth Factor Rev 7:249-258. CrossRef Medline

Kästner S, Elias MC, Rivera AJ, Yablonka-Reuveni Z (2000) Gene expression patterns of the fibroblast growth factors and their receptors during myogenesis of rat satellite cells. J Histochem Cytochem 48:1079-1096. CrossRef Medline

Kennel PF, Finiels F, Revah F, Mallet J (1996) Neuromuscular function impairment is not caused by motor neurone loss in FALS mice: an electromyographic study. Neuroreport 7:1427-1431. CrossRef Medline

Kim MJ, Cotman SL, Halfter W, Cole GJ (2003) The heparan sulfate proteoglycan agrin modulates neurite outgrowth mediated by FGF-2. J Neurobiol 55:261-277. CrossRef Medline

Kim N, Stiegler AL, Cameron TO, Hallock PT, Gomez AM, Huang JH, Hubbard SR, Dustin ML, Burden SJ (2008) Lrp4 is a receptor for Agrin and forms a complex with MuSK. Cell 135:334-342. CrossRef Medline

Kishi M, Kummer TT, Eglen SJ, Sanes JR (2005) LL5beta: a regulator of postsynaptic differentiation identified in a screen for synaptically enriched transcripts at the neuromuscular junction. J Cell Biol 169:355-366. CrossRef Medline

Koles K, Budnik V (2012) Wnt signaling in neuromuscular junction development. Cold Spring Harb Perspect Biol 4: pii: a008045. CrossRef Medline

Li Y, Lee Yi, Thompson WJ (2011) Changes in aging mouse neuromuscular junctions are explained by degeneration and regeneration of muscle fiber segments at the synapse. J Neurosci 31:14910-14919. CrossRef Medline

McCann CM, Nguyen QT, Santo Neto H, Lichtman JW (2007) Rapid synapse elimination after postsynaptic protein synthesis inhibition in vivo. J Neurosci 27:6064-6067. CrossRef Medline

Mendias CL, Gumucio JP, Davis ME, Bromley CW, Davis CS, Brooks SV (2012) Transforming growth factor-beta induces skeletal muscle atrophy and fibrosis through the induction of atrogin-1 and scleraxis. Muscle Nerve 45:55-59. CrossRef Medline

Mews M, Meyer M (1993) Modulation of Schwann cell phenotype by TGFbeta 1: inhibition of P0 mRNA expression and downregulation of the low affinity NGF receptor. Glia 8:208-217. CrossRef Medline

Moloney EB, de Winter F, Verhaagen J (2014) ALS as a distal axonopathy: molecular mechanisms affecting neuromuscular junction stability in the presymptomatic stages of the disease. Front Neurosci 8:252. CrossRef Medline

Morrison-Nozik A, Anand P, Zhu H, Duan Q, Sabeh M, Prosdocimo DA, Lemieux ME, Nordsborg N, Russell AP, MacRae CA, Gerber AN, Jain MK, Haldar SM (2015) Glucocorticoids enhance muscle endurance and ameliorate Duchenne muscular dystrophy through a defined metabolic program. Proc Natl Acad Sci U S A 112:E6780-E6789. CrossRef Medline

Ray R, Cabal-Manzano R, Moser AR, Waldman T, Zipper LM, Aigner A, Byers SW, Riegel AT, Wellstein A (2003) Up-regulation of fibroblast growth factor-binding protein, by beta-catenin during colon carcinogenesis. Cancer Res 63:8085-8089. Medline

Rocha MC, Pousinha PA, Correia AM, Sebastião AM, Ribeiro JA (2013) Early changes of neuromuscular transmission in the SOD1(G93A) mice model of ALS start long before motor symptoms onset. PLoS One 8:e73846. CrossRef Medline 
Samuel MA, Valdez G, Tapia JC, Lichtman JW, Sanes JR (2012) Agrin and synaptic laminin are required to maintain adult neuromuscular junctions. PLoS One 7:e46663. CrossRef Medline

Sandri M, Sandri C, Gilbert A, Skurk C, Calabria E, Picard A, Walsh K, Schiaffino S, Lecker SH, Goldberg AL (2004) Foxo transcription factors induce the atrophy-related ubiquitin ligase atrogin-1 and cause skeletal muscle atrophy. Cell 117:399-412. CrossRef Medline

Sanes JR, Lichtman JW (1999) Development of the vertebrate neuromuscular junction. Annu Rev Neurosci 22:389-442. CrossRef Medline

Sanes JR, Lichtman JW (2001) Induction, assembly, maturation and maintenance of a postsynaptic apparatus. Nat Rev Neurosci 2:791-805. Medline

Sanyal S, Kim SM, Ramaswami M (2004) Retrograde regulation in the CNS; neuron-specific interpretations of TGF-beta signaling. Neuron 41:845848. CrossRef Medline

Sanz E, Yang L, Su T, Morris DR, McKnight GS, Amieux PS (2009) Celltype-specific isolation of ribosome-associated mRNA from complex tissues. Proc Natl Acad Sci U S A 106:13939-13944. CrossRef Medline

Seale P, Asakura A, Rudnicki MA (2001) The potential of muscle stem cells. Dev Cell 1:333-342. CrossRef Medline

Sheehan SM, Allen RE (1999) Skeletal muscle satellite cell proliferation in response to members of the fibroblast growth factor family and hepatocyte growth factor. J Cell Physiol 181:499-506. CrossRef Medline

Si Y, Kim S, Cui X, Zheng L, Oh SJ, Anderson T, AlSharabati M, Kazamel M, Volpicelli-Daley L, Bamman MM, Yu S, King PH (2015) Transforming growth factor beta (TGF- $\beta$ ) is a muscle biomarker of disease progression in ALS and correlates with Smad expression. PLoS One 10:e0138425. CrossRef Medline

Tassi E, Al-Attar A, Aigner A, Swift MR, McDonnell K, Karavanov A, Wellstein A (2001) Enhancement of fibroblast growth factor (FGF) activity by an FGF-binding protein. J Biol Chem 276:40247-40253. CrossRef Medline

Tassi E, Walter S, Aigner A, Cabal-Manzano RH, Ray R, Reier PJ, Wellstein A (2007) Effects on neurite outgrowth and cell survival of a secreted fibroblast growth factor binding protein upregulated during spinal cord injury. Am J Physiol Regul Integr Comp Physiol 293:R775-R783. CrossRef Medline

Tassi E, McDonnell K, Gibby KA, Tilan JU, Kim SE, Kodack DP, Schmidt
MO, Sharif GM, Wilcox CS, Welch WJ, Gallicano GI, Johnson MD, Riegel AT, Wellstein A (2011) Impact of fibroblast growth factor-binding protein-1 expression on angiogenesis and wound healing. Am J Pathol 179:2220-2232. CrossRef Medline

Terauchi A, Johnson-Venkatesh EM, Toth AB, Javed D, Sutton MA, Umemori H (2010) Distinct FGFs promote differentiation of excitatory and inhibitory synapses. Nature 465:783-787. CrossRef Medline

Umemori H (2009) Weaving the neuronal net with target-derived fibroblast growth factors. Dev Growth Differ 51:263-270. CrossRef Medline

Valdez G, Tapia JC, Kang H, Clemenson GD Jr, Gage FH, Lichtman JW, Sanes JR (2010) Attenuation of age-related changes in mouse neuromuscular synapses by caloric restriction and exercise. Proc Natl Acad Sci U S A 107:14863-14868. CrossRef Medline

Valdez G, Heyer MP, Feng G, Sanes JR (2014) The role of muscle microRNAs in repairing the neuromuscular junction. PLoS One 9:e93140. CrossRef Medline

Valsecchi V, Boido M, De Amicis E, Piras A, Vercelli A (2015) Expression of muscle-specific MiRNA 206 in the progression of disease in a murine SMA model. PLoS One 10:e0128560. CrossRef Medline

Walter MA, Kurouglu R, Caulfield JB, Vasconez LO, Thompson JA (1993) Enhanced peripheral nerve regeneration by acidic fibroblast growth factor. Lymphokine Cytokine Res 12:135-141. Medline

Williams AH, Valdez G, Moresi V, Qi X, McAnally J, Elliott JL, Bassel-Duby R, Sanes JR, Olson EN (2009) MicroRNA-206 delays ALS progression and promotes regeneration of neuromuscular synapses in mice. Science 326 : 1549-1554. CrossRef Medline

Winbanks CE, Wang B, Beyer C, Koh P, White L, Kantharidis P, Gregorevic P (2011) TGF-beta regulates miR-206 and miR-29 to control myogenic differentiation through regulation of HDAC4. J Biol Chem 286:1380513814. CrossRef Medline

Wu DQ, Kan MK, Sato GH, Okamoto T, Sato JD (1991) Characterization and molecular cloning of a putative binding protein for heparin-binding growth factors. J Biol Chem 266:16778-16785. Medline

Zheng HQ, Zhou Z, Huang J, Chaudhury L, Dong JT, Chen C (2009) Krüppel-like factor 5 promotes breast cell proliferation partially through upregulating the transcription of fibroblast growth factor binding protein 1. Oncogene 28:3702-3713. CrossRef Medline 